DR. ILANA N ACKERMAN (Orcid ID : 0000-0002-6028-1612)

PROF. ANDREW M BRIGGS (Orcid ID : 0000-0002-6736-3098)

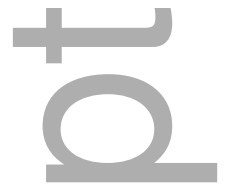

Article type : Original Article

\title{
A systematic review of the impact of inflammatory arthritis on intimate relationships and sexual function
}

\section{Laura J. Restoux, BPT}

School of Physiotherapy and Exercise Science, Curtin University, Western Australia, Australia Silpa R. Dasariraju, MPT

School of Physiotherapy and Exercise Science, Curtin University, Western Australia, Australia Ilana N. Ackerman, BPhysio(Hons), PhD

Associate Professor, Department of Epidemiology and Preventive Medicine, Monash University, Victoria, Australia

\section{Sharon Van Doornum, MBBS, FRACP, MD, Grad Dip Clin Epi}

Associate Professor, Melbourne Health and Department of Medicine, The University of Melbourne, Victoria, Australia

This is the author manuscript accepted for publication and has undergone full peer review but has not been through the copyediting, typesetting, pagination and proofreading process, which may lead to differences between this version and the Version of Record. Please cite this article as doi: $10.1002 /$ ACR.23857

This article is protected by copyright. All rights reserved 


\section{Lorena Romero, MBIT, BA}

Research Librarian, Alfred Medical Research and Education Precinct, Victoria, Australia Andrew M. Briggs, BSc(PT)Hons, PhD, FACP*

Professor, School of Physiotherapy and Exercise Science, Curtin University, Western Australia, Australia

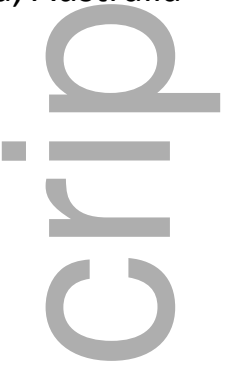

*Correspondence to:

Professor Andrew Briggs, PhD, FACP

School of Physiotherapy and Exercise Science,

Faculty of health Sciences, Curtin University,

GPO Box U1987, PERTH, 6845

Western Australia, Australia

Phone: +61 892664644

Fax: +61 892663699

Email: A.Briggs@curtin.edu.au

Running head: Inflammatory arthritis and sexual function

Word count: 3800 (not including abstract, references, tables and figure legends)

\section{Funding sources}

AMB is supported by a fellowship awarded by the Australian National Health and Medical Research Council (\#1132548). INA is supported by a Victorian Health and Medical Research Fellowship awarded by the Victorian Government. We acknowledge funding support through an investigator-initiated, unrestricted grant-in-aid from UBC Australia Pty Ltd and AbbVie Australia.

\section{Disclosure of Interest}


The authors have no conflicts of interest or financial interests to disclose

\section{ABSTRACT}

Objective: To systematically review evidence of the impact of inflammatory arthritis (IA) on, or association of IA with, intimate relationships and sexual function.

Methods: Ovid Medline, Ovid PsycINFO, Ovid EMBASE and EBSCO CINAHL databases were searched. Two independent reviewers selected articles, extracted data and conducted manual searches of reference lists from included studies and previous reviews. The quality of evidence was assessed using standard risk of bias tools.

Results: Fifty-five eligible studies were reviewed. Of these, 49 (89\%) were quantitative, five (7.2\%) were qualitative and one (3.6\%) used a mixed-method design. Few quantitative studies were rated as low risk of bias $(n=7 ; 14 \%)$, many were rated as moderate $(n=37 ; 74 \%)$ or high risk ( $n=6 ; 12 \%$ ). Quantitative study sample sizes ranged from 10-1,272 participants with reported age range 32-63 years. Qualitative study sample sizes ranged from 8-57 participants with reported age range 20-69 years. In studies reporting the Female Sexual Function Index, all IA groups demonstrated mean scores $\leq 26.55$ (range of mean (SD) scores: 14.2(7.8)-25.7(4.7)), indicating sexual dysfunction. In studies reporting the International Index of Erectile Function, all IA groups reported mean scores $\leq 25$ (range of mean (SD) scores: $16.3(6.2)-24.5(6.0))$, indicating erectile dysfunction. Key qualitative themes were impaired sexual function and compromised intimate relationships; prominent sub-themes included IA-related pain and fatigue, erectile dysfunction, diminished sexual desire, and sexual function fluctuations according to disease activity.

Conclusion: Sexual dysfunction appears highly prevalent amongst men and women with IA, and increased clinician awareness of this impairment may guide provision of tailored education and support.

\section{Key words}

relationship; intimacy; sexual function; inflammatory arthritis; impact 


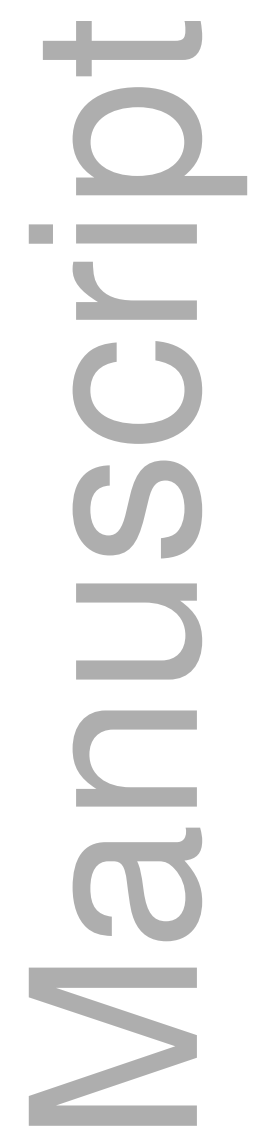

\section{SIGNIFICANCE AND INNOVATIONS}

- This is the first systematic review to consider the impact of all types of inflammatory arthritis (IA) on intimate relationships and sexual function in both genders based on evidence from qualitative and quantitative studies.

- Eligible studies were primarily quantitative in design and demonstrated a higher prevalence of sexual dysfunction amongst the IA population in comparison to healthy populations; however, the impact on intimate relationships was rarely explored.

- Qualitative studies revealed that sexual dysfunction was impaired in IA due to pain, reduced sexual desire, erectile dysfunction and fatigue, along with the same 
stressors that affect the general population such as stress, education and other concerns.

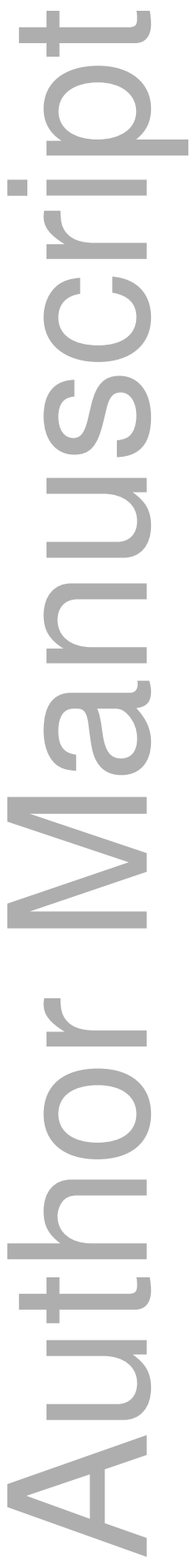

This article is protected by copyright. All rights reserved 
1 The International Classification of Functioning, Disability and Health (ICF) considers sexual health as comprising two distinct constructs: "sexual function", relating to body functions, and "intimate relationships", relating to activity and participation.(1) Sexual function in people with inflammatory arthritis (IA) may be affected by disease activity (pain, functional limitations and fatigue); psychological distress related to the disease including reduced selfesteem and altered body image perception; and/or side effects from pharmacological treatments (fatigue, lowered mood, vaginal dryness and erectile dysfunction).(2-10) Intimate relationships may, in turn, be affected by these and other factors, $(11,12)$ potentially contributing to relationship dissatisfaction and family breakdown.(2,13-15) The impact of IA on sexual health appears to be an issue worldwide as it has been identified in populations in Europe, America, Asia and Africa.(13,16-19)

Sexual health and family planning are important considerations not only for individuals living with IA but also for the health practitioners who treat them,(20) yet these issues are rarely comprehensively addressed in clinical practice. $(4,8,9,16,18,19,21-24)$ Earlier research has shown that $36-70 \%$ of people with rheumatoid arthritis (RA) experience impaired sexual health associated with their disease, $(5,7,13,16,19,21,22,25,26)$ however, the majority have not discussed this with a health professional.(27) Additionally, people with IA vary in their preference of health professional with whom to discuss these issues(27), suggesting all health professionals involved in a person's care should gain an improved understanding of the potential impacts of IA on sexual function and intimate relationships,.

The impact of IA on sexual health has been investigated previously, however systematic reviews published to date have important limitations. $(5,6,28,29)$ First, many have not assessed the impact of IA on both genders, as most have focused on female sexual function only.(29-39) Second, most reviews have been disease-specific,(6,28-34,36-51) limiting transferability of the findings to other IA conditions. Although some reviews have considered rheumatic conditions more broadly, $(10,35,52,53)$ they do not include contemporary evidence. $(3,10,21,22,54-102)$ Finally, earlier reviews have largely been restricted to Western populations. $(6,28)$

To overcome existing limitations, we aimed to undertake a systematic review of selfreported perceptions (concerns, thoughts, beliefs, opinions) concerning the impact of IA on, 
or the association of IA with, intimate relationships and sexual function among people with IA.

\section{MATERIALS AND METHODS}

\section{Study design}

A systematic review of quantitative and qualitative studies was undertaken in 2018 . The systematic review protocol was registered on the PROSPERO International Prospective Register of Systematic Reviews (registration number CRD42017074189). The review is reported according to the Preferred Reporting Items for Systematic Reviews and MetaAnalysis (PRISMA) statement (Supplementary file).

\section{Eligibility for inclusion}

Primary qualitative, quantitative and mixed-method design studies published in English in peer-reviewed journals were included. Relevant self-reported outcomes included concerns, thoughts, beliefs and opinions of people with IA, concerning the impact of their IA on, or the association of IA with, intimate relationships and sexual function and were drawn from quantitative studies (e.g. surveys) or qualitative studies (e.g. interviews, focus groups). Studies conducted in any care setting were included. Studies that included males or females with a diagnosis of IA (including but not limited to rheumatoid arthritis (RA), seronegative arthritis, systemic lupus erythematous (SLE), systemic scleroderma/sclerosis (SSc), ankylosing spondylitis (AS), psoriatic arthritis (PSA), connective tissue disease (CTD), vasculitis, Sjogren's Syndrome (SS), spondyloarthritis ( $\mathrm{SpA}$ ), auto-immune arthritis, and juvenile idiopathic arthritis (JIA)) were included. Patients aged $\geq 16$ years were eligible for the inclusion. Studies where the outcomes were not directly reported by people who live with IA (e.g. Where outcomes were only reported by spouses) were excluded. Abstracts and conference proceedings were also excluded.

\section{Search strategy and selection of studies}

Four electronic databases (Ovid Medline, Ovid PsycINFO, Ovid EMBASE and EBSCO CINAHL Plus) were searched systematically from 1st of January 1990 to 8th of May 2018. An initial 
search for studies was conducted in Medline and EMBASE, and an analysis of text words and subject terms was then used to develop the search (LR). Subject classification systems for each database were also investigated (with input from INA, SVD and AMB). The final searches of all four electronic databases was executed using the appropriate specifications of each database (LR). The comprehensive search strategy used for each of the four databases is presented in the Supplementary file. Grey literature was not considered. Two reviewers (LJR and SRD) independently screened the titles and abstracts of the yield to determine each paper's eligibility for inclusion. Any discordance regarding eligibility was discussed and resolved through consensus with arbitration by a third reviewer (AMB), if required. The full texts of the potentially eligible papers were reviewed independently by two reviewers (LR and SRD) to confirm eligibility. Any discordance in selection of full texts was resolved through consensus and arbitrated by a third reviewer (AMB), if required. The reference lists of all included full text studies and any systematic reviews identified were manually screened by the reviewers (LR and SRD). Citation screening and selection was documented and summarized in a PRISMA-compliant flow chart (Figure 1).

\section{Data extraction}

Data extraction was undertaken by two reviewers independently (LR and SRD) and a consensus dataset derived. A standardised data extraction template was developed using Microsoft Excel (Microsoft Corporation, Albuquerque, New Mexico, United States) and piloted on three eligible papers by LJR, SRD, INA, SVD and AMB. Data from quantitative and qualitative studies were extracted separately. The following data were extracted (where available) for each study: research question, study design, study population including diagnoses, geographic region, study setting, demographic characteristics (e.g. age, gender), primary and secondary outcome measures and results. For qualitative studies, the first order data (the quotes from the primary study participants) and the second order data (themes, sub-themes developed by authors of included papers) were extracted to preserve the links to the original quotes and the context from the primary study.

\section{Quality and risk of bias appraisal}

The methodologic quality of the included studies was appraised independently by two reviewers (LJR and SRD) and a consensus appraisal score derived. Quantitative studies were 
appraised using the Hoy et al risk of bias tool,(103) while the Critical Appraisal Skills Program (CASP) tool was used for qualitative studies.(104) While there are several risks of bias assessment tools available for quantitative and qualitative studies, these tools were selected for ease of use and alignment with other patient-centred systematic reviews relevant to rheumatic diseases.(105-110). The tools were piloted on three eligible papers to ensure inter-rater consistency. Any discordance regarding critical appraisal was discussed and resolved through consensus with arbitration by a third reviewer (AMB), if required.

\section{Data analysis and synthesis of results}

Two reviewers (LJR and SRD) independently extracted and synthesised the data from the eligible studies. Descriptive and outcome data from quantitative studies were summarised and reported descriptively. The independent datasets relating to the quantitative studies were compared for consistencies, with any discrepancies resolved to create a composite dataset. The results of the qualitative studies were meta-synthesised using a staged approach of thematic analysis.(111-113) Independent data files were merged and compared with discrepancies resolved by consensus, and if necessary, arbitration. First, each reviewer read the full text paper multiple times highlighting relevant sections that related to the review to inductively develop initial categories or themes. These themes/categories were organised into an initial thematic framework, which was reviewed by other authors (AMB, INA, SVD) to consider construct validity and clinical meaningfulness. Second, the framework was populated with extracted data from the studies to ensure the inductively-derived themes and sub-themes were underpinned by primary data. Once populated, the framework was again revised and reviewed by the authors.

\section{Assessment of confidence profile}

The GRADE-Confidence in the Evidence from Reviews of Qualitative research (GRADECERQual) method was used to assess confidence in the meta-synthesis findings across four domains: 1) methodological limitations, 2) coherence, 3) adequacy of data, and 4) relevance of all the individual primary research study findings contributing to the meta-synthesis,(114) with each domain assigned a level of concern (minor, moderate, substantial). The review team (SRD, LR, AMB) evaluated the confidence profile through discussions and allocated an overall level of confidence (high, moderate, low and very low confidence) to each finding in the meta-synthesis. 
RESULTS

\section{Search results and description of included studies}

124 The search strategy returned 2100 unique citations of which 55 (2.6\%) (7-9,19,22,27,6077,79-102,115-121) met the inclusion criteria (Figure 1). Descriptive characteristics of the 55 included studies are summarised in Table 1. Of the included studies, 50 (90.1\%) were quantitative, $(7,9,19,27,60-76,79,81,82,84-88,90-94,96-102,115-121)$ five (9.1\%) were qualitative $(77,80,83,89,95)$ and one $(1.8 \%)$ used a mixed-method design.(8) Four of the qualitative studies used focus groups or semi-structured interviews, $(80,83,89,95)$ while all the quantitative studies used patient-reported questionnaires. $(7,9,19,22,27,60-76,79$, $81,82,84-88,90-94,96-102,115-121)$

Included studies were conducted, where reported, in the European Union ( $n=16 ; 29 \%),(8$, $19,27,62,69,79,83,87,89,90,94-98,117)$ Middle East ( $n=14 ; 25.4 \%),(22,65,67,68,71,75,77,80$, $84,86,91,100,118,121)$ North America $(n=5 ; 9 \%),(60,63,97,115,116)$ Africa $(n=3$; $5.4 \%),(7,85,88)$ Oceania $(n=1 ; 1.8 \%)(70)$ and in South America $(n=2 ; 3.6 \%) .(66,92)$ Controlled cohort study designs were adopted by 33 (69\%) of the quantitative studies, $(9,19,22,60,61,64-69,71,72,75,81,82,84-87,91,92,96-102,115,118,120)$ while 12 (30.9\%) used single group designs. $(7,62,63,70,74,76,88,93,94,116,117,119)$ Sixteen $(29 \%)$ studies sampled people with RA only, $(7,9,19,27,68,75,82-85,88,93,94,96,100,118) 16(29 \%)$ with AS only, $(22,61,62,64-66,71-74,80,81,92,119-121)$ nine (16.3\%) with SS only, $(63,69,76$, $77,79,90,97,115,117)$ five $(9 \%)$ with SLE only, $(60,70,89,99,116)$ four $(7.2 \%)$ with SS only, $(87,91,101,102)$ and three $(5.4 \%)$ with mixed inflammatory arthritis conditions.(74) Mean (SD) IA disease duration ranged from 3.3 (2.6) years to 19.0 (11.6), 52 (94.5\%) studies reported participants had a disease duration of greater than five years. (7-9,19,27,60-70,72$77,79-82,84-102,115-121)$

Participants were recruited from tertiary hospital outpatient rheumatology clinics in eight (14\%) studies, $(9,19,62,67,70,81,84,93,95)$ research hospital outpatient rheumatology clinics in four $(7 \%)$ studies, $(8,72,100,118)$ non-tertiary outpatient rheumatology clinics in six $(10 \%)$ studies, $(7,69,71,74,98,99)$ university hospitals in $15(27 \%)$ studies $(22,63,65,66,75-$ 
$77,80,85,87,88,91,92,122)$ and from research or disease databases/registries in seven (12\%) studies. $(60,89,96,97,115-117,121)$ Sample size ranged from 10-1,272 participants (reported age range: 32-63 years; proportion female: $0-100 \%)$ in quantitative studies $(7,19,22,27,60$ 76,79,81,82,84-88,90-94,96-102,115-121) and 8-57 participants (reported age range: 20-69 years; proportion female: $30-53 \%)$ in qualitative and mixed-method studies. $(8,77,80,83$, $89,95)$

\section{Outcomes reported}

Outcomes from quantitative studies highlighted that sexual dysfunction was more prevalent among people with IA for both men and women compared with controls (Table 2). The two most common instruments were the Female Sexual Function Index (FSFI) and the International Index for Erectile Function (IIEF).

FSFI scores were reported in 15 (30\%) studies (Figure 2). All patient groups demonstrated a mean score lower than the FSFI threshold for sexual dysfunction of $\leq 26.55$ (123), indicating the presence of sexual dysfunction. $(22,68,69,71,72,76,82,86,87,90,91,98,99,101,102)$ Of these 15 studies, 13 (87\%) compared an IA patient group with a control group, highlighting that most of the IA groups had lower FSFI mean scores than controls. $(22,68,69,71,72,82,86,87,91,98,99,101,102)$ In two studies $(13 \%)$, control groups demonstrated greater sexual dysfunction than the IA patient groups. $(71,82)$ In five $(38 \%)$ studies, control groups reported sexual dysfunction, based on the FSFI threshold, although their mean scores were still higher than IA patient groups.(68,69,71,82,101) Two studies (13\%) did not utilise control groups, however, the mean scores reported for their IA groups on the FSFI appeared much lower than the mean scores of studies with control groups. $(76,90)$ Comparing outcomes by disease, populations with SSc reported mean FSFI scores that tended to be the lowest, $(69,76,90,98)$ although these studies were uncontrolled. $(76,90)$

Seven (14\%) studies used the IIEF to assess the impact of IA on men's erectile function $(64,67,75,81,90,120,121)$ (Figure 3). In all studies, $(64,67,75,81,90,120,121)$ the mean IIEF scores were $\leq 25$, indicating erectile dysfunction.(124) All but one study compared IIEF scores of IA patients to controls and found lower mean scores in the IA group. $(64,67,75,81,120,121)$ Mean scores for most control groups suggested normal erectile 
function except for two studies where the control group mean scores were on the threshold for erectile dysfunction, however these scores were not lower than the IA patients' mean scores. $(64,81)$ One study did not involve comparison with a control group, although the mean IIEF score remained lower compared to mean scores of IA groups across other studies.(90) Comparing outcomes by disease, a population with SSc reported the lowest mean IIEF score, (90) followed by AS groups $(64,67,81,120,121)$, while those with RA appeared to have the highest IIEF mean score.(75)

Twenty-six (52\%) studies reported outcome measures that included other validated and reliable tools, shortened versions of existing tools, or customised tools for that specific study.(7-9,19,27,60-62,65,66,70,73,74,79,84,85,93,94,96,97,100,115-119) All identified sexual dysfunction amongst their IA groups, however few commented on the impact of IA on intimate relationships. $(8,62)$ In those that did, only the prevalence of disrupted relationships was explored, which was reported by $38 \%$ of men with AS $(62,96)$ and $25 \%$ $76 \%$ of males and females with RA. $(8,96)$ Among the 12 (43\%) studies that compared outcomes with control groups, impaired sexual function was more consistently reported by patients with IA, compared to controls. $(9,19,61,65,66,74,84,92,97,100,115,118)$. Scope of sexual dysfunction measured in these studies involved the degree of sexual or erectile dysfunction; $(7,9,27,60-62,65,85,95,96,100,117-119,125)$ prevalence of sexual dysfunction; $(8,70,73,93,97)$ prevalence of patients engaging, initiating and avoiding intercourse and foreplay;(126) satisfaction with sexual life;(74) and individual domains of sexual function (including desire, masturbation, fantasies, frequency, fatigue, pain, sensation, lubrication, orgasm, intensity of orgasms and overall sexual satisfaction).(66,84,115)

Subject data collection, $(7,9,19,22,27,60-65,67-69,71-76,79,81,82,84-86,88,90$ 94,98,99,101,115-121) acceptable case definition,(7,9,19,22,60-62,64-76,79,81,82,8486,88,90-94,96-100,115-121) mode of data collection,(7-9,19,22,27,60-69,71-76,79,81,82, 84-86,88,90-94,96-100,115-121) a short prevalence period, $(9,19,22,60,62-65,67-69,71-$ $76,79,82,84-86,88,90-93,96-100,118-121)$ and validity of measurement tools $(7,9,19,22$, $60,62-65,67-69,71-73,75,79,81,82,84,86,88,90-92,96-100,117,119-121)$ were the most common shortfalls across included studies. Most $(n=37,74 \%)$ quantitative studies were assessed as having a moderate risk of bias $(7,8,22,60,61,63,64,68-71,74-76,79,81,82,84-$ 

risk of bias, $(62,65,67,72,87,91,99)$ while $6(12 \%)$ were assessed as having a high risk of bias. $(9,19,27,66,73,102)$ Risk of bias in these high risk studies was primarily related to internal validity considerations (mode of data collection, case definition, reliable and acceptable diagnosis, short period for determining prevalence).(9,19,27,66,102)

\section{Meta-synthesis of qualitative data}

217 Meta-synthesis outcomes for the six eligible qualitative studies are summarised in Table 3. Two key themes were identified, supported by several sub-themes.

Theme 1: Impaired sexual function

Subtheme analysis demonstrated that sexual function was affected by pain, reduced sexual desire, erectile dysfunction and fatigue, along with the same stressors that affect the general population such as stress, education and other general life concerns. $(8,80,95,122)$ People with IA reported that they typically changed the positions previously adopted during intercourse, assuming a more passive role to reduce pain. $(80,95)$ Pain was associated with a fear of interrupted intercourse, or intercourse being postponed. $(80,95)$ Level of sexual dysfunction often varied with flares in disease activity, but also with time of day, as pain and fatigue were more likely to affect sexual dysfunction during the evening. $(95,122)$ Erectile dysfunction largely accounted for sexual dysfunction in males, which caused frustration, shock, stress and a sense of emasculation. $(95,122)$ Negative body image, reduced desire for intercourse and erectile dysfunction all contributed to an altered sense of sexuality across both genders. $(89,95,122)$

\section{Theme 2: Compromised intimate relationships}

Intimate relationships tended to transition towards a more caring and less physical nature as the importance of sexual intercourse was reduced, particularly during disease flares.(95) Some partners had greater acceptance and understanding of the impact IA had on sexual function than others, assisting to strengthen relationships between partners.(8) Others found that their partners poorly understood the impact of IA on their ability to engage in 
intercourse, creating tension and fear in relationships. $(77,95,122)$ Despite the sexual dysfunction associated with IA, women often felt pressured to maintain a normal sex life to prevent relationships being compromised by IA. $(8,95)$ Poor body image reduced sexual desire in both male and female populations and restricted people from finding partners.(95)

Quality assessment of the qualitative studies is summarised in the Supplementary file. Many of the qualitative studies were considered to have a risk of bias due to lack of consideration of the relationship between researcher and their participants, $(8,77,80,89,95)$ ethical issues (95) or a failure to clearly state the research aims.(89)

Confidence in the meta-synthesis findings was evaluated based on the four domains of the GRADE-CERQual approach (Supplementary file). Overall, we identified 11 key findings based on the summary of results from primary studies (Table 3); two were associated with a high level of confidence that the review findings were a reasonable representation of the phenomenon of interest, while three were rated as moderate confidence and three were rated as very low confidence.

\section{DISCUSSION}

We identified consistent evidence (albeit of varying methodological quality) highlighting an association between IA and impacts on intimate relationships and sexual function for both genders. People living with IA consistently demonstrated a higher prevalence of sexual dysfunction compared to healthy peers, although these estimates tend to be crude and are not adjusted for potential confounders. For both genders, disease-related factors contributed to sexual dysfunction (including pain, fatigue and mobility restrictions) and reduced sexual desire, as well as non-disease-related factors that typically affect the general population. Erectile dysfunction and its emotional sequelae largely accounted for sexual dysfunction while females experienced pressured to continue intimate relationships despite their sexual dysfunction, causing stress in relationships. $(8,95,122)$

Our review demonstrated that studies have primarily assessed the impact of IA on sexual function utilising the FSFI and IIEF instruments. All studies using the FSFI demonstrated that IA populations had a mean score lower than the FSFI threshold of $\leq 26.55$ (123) indicating the 
prevalence of sexual dysfunction compared to healthy controls. $(22,68,69,71,72,76,82$, $86,87,90,91,98,99,101,102)$ Two studies found that healthy populations demonstrated greater sexual dysfunction than their matched IA populations. $(71,82)$ Demir et al. $(71)$ suggested this may be due to excluding psychiatric history and antidepressant use, which may have reduced the prevalence of mental health conditions and sexual dysfunction sequelae amongst the IA group. However, four other studies used these exclusion criteria and their IA populations had greater sexual dysfunction than controls and no statistically significant difference in depression between the IA group and healthy controls was observed. $(22,68,86,91)$ Hari et al.(82) reported healthy controls had lower FSFI mean scores than the IA population with both groups falling into the sexual dysfunction category, but sexual dysfunction was highest amongst the IA group (76\%) compared with healthy controls (47.5\%).

Several included studies used the IIEF as an outcome measure and demonstrated mean scores of $\leq 25$ indicating erectile dysfunction in IA populations. $(43,64,67,75,81,90,120$, $121,124)$ Two studies reported control group mean scores were on the threshold for erectile dysfunction, however these scores were not lower than the IA patients' mean scores. $(64,81)$ Bal et al. (64) reported that these scores were not significantly different between groups, however due to a small sample size this study likely lacked adequate statistical power to observe meaningful difference. While mean scores of the control group in the study by Dhakad et al. (81) also suggested erectile dysfunction, IIEF mean scores of the IA group were significantly lower. As erectile dysfunction has a multifactorial aetiology, and numerous risk factors have been identified, this may also explain the prevalence of this condition amongst healthy controls. $(127,128)$ However, on a background of other disease-related impacts in men (such as pain, mobility restrictions and fatigue), IA appears to be consistently related to impaired sexual function and a key contributor to compromised intimate relationships.

The synthesised qualitative data support the quantitative findings, providing further evidence about the impact of IA on sexual health and relationships. While clinical tools such as the FSFI and IIEF were useful in quantifying sexual dysfunction, data from the included qualitative studies provided more in-depth insights, particularly with respect to how intimate relationships were compromised. This appeared to differ across studies and samples and may also reflect the dynamics of individual relationships. For example, some 
participants reported a decreased focus on sexual intercourse while others felt pressured to maintain intimate relationships despite their apparent sexual dysfunction. $(8,95)$ This may also reflect varying levels of partners' understanding of the sexual dysfunction associated with IA. Partners with a greater understanding assisted to strengthen relationships while among those who poorly understood disease impacts, tension and fear were created within relationships. $(8,77,95,122)$

The strengths of this review included our comprehensive systematic review methods, which involved a specialist research librarian during search strategy development, and the involvement of at least two independent reviewers at every stage of the review process. Unlike previous reviews (29-39), both genders were considered, quantitative and qualitative study designs were included, and all types of IA were included, whereas previous reviews were mostly disease-specific. $(6,28-34,36-51)$ The review also covered a broad range of geographic regions. Overall risk of bias for the qualitative studies was reasonably low, according to the CASP tool.(104) The GRADE-CERQual evaluation provides moderate confidence that the review findings can be used to appropriately answer our research question.

We also acknowledge the review limitations. We were unable to conduct a meta-analysis given heterogeneity of study populations and outcome measures, and some of the included quantitative studies were of poor methodological quality. Overall, $74 \%$ of the quantitative studies were considered to have a moderate risk of bias, suggesting that further research is likely to have an impact on our confidence of these findings. Nonetheless, the included studies represent the contemporary evidence base and provide consistent evidence of an association between IA and sexual dysfunction. While grey literature was not systematically searched, we are confident that the comprehensive nature of our search strategy identified the breadth of evidence relating to IA and sexual function and intimacy. Given the consistency identified in quantitative and qualitative data, we do not expect that unpublished work would change our overall findings. We observed a limited range of outcome measures reported in quantitative studies, which may introduce an outcomes bias when interpreting the available evidence. Due to the small number of eligible qualitative studies, meta-synthesis was limited as themes and sub-themes were drawn from only six studies. $(8,77,80,89,95,122)$ Furthermore, most studies explored impact on sexual function 
rather than intimate relationships. Finally, from the data available we are unable to speculate on the temporal nature of the association between disease and sexual dysfunction and compromised relationships (since most studies sampled people with a disease duration of IA of five years or more) and whether age, disease duration, management approaches or other health-related factors are likely to mediate the relationship. This represents an important area for future research. Based on the volume and quality of evidence reviewed, potential biases associated with cross-sectional studies and importance of the topic to patients, we suggest the impact of the findings is moderate.

Our review identified that many types of IA have substantial impacts on sexual function and intimate relationships. These issues are sensitive in nature and commonly addressed poorly in clinical practice as they may be embarrassing for the clinician and/or the patient to raise. $(8,9,18,19,21-24,56,59,129)$ Our findings can be used to increase clinicians' awareness and thus encourage discussions with their patients from the early stages of management. While raising these issues in initial consultations may be difficult given competing disease priorities and the need to establish rapport and active disease management, our findings suggest that sexual health and relationships are important components of overall health and should therefore be components of routine IA management.

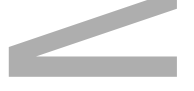

\section{CONCLUSION}

Sexual dysfunction is prevalent in female and male populations diagnosed with various forms of IA. Sexual dysfunction in IA is associated with pain, reduced sexual desire, erectile dysfunction, fatigue and mobility restrictions. As sexual health is an important component of wellbeing, raising clinician and patient awareness of sexual dysfunction associated with IA could facilitate the provision of more holistic care.

\section{Acknowledgements}

The authors thank Dr Leo Ng (Curtin University) for comments on the systematic review protocol and manuscript. 
360 1. World Health Organization [Internet]. International Classification of Functioning, Disability and Health [cited 2018 mar 29] Geneva: WHO Library Cataloguing-in-Publication Data; 2001 [Available from: http://psychiatr.ru/download/1313?view=name=CF_18.pdf]. 2. Elst P, Sybesma T, van der Stadt RJ, Prins AP, Muller WH, den Butter A. Sexual problems in rheumatoid arthritis and ankylosing spondylitis. Arthritis Rheumatol [Internet]. $1984 ; 27: 217-20$.

3. Lin M, Lu M, Livneh H, Lai N, Guo H, Tsai T. Factors associated with sexual dysfunction in Taiwanese females with rheumatoid arthritis. BMC Womens Health [Internet]. 2017;17(1):12.

4. Akkus Y, Nakas D, Kalyoncu U. Factors affecting the sexual satisfaction of patients with rheumatoid arthritis and ankylosing spondylitis. Sex Disabil [Internet]. 2010;28(4):22332.

5. Kraaimaat FW, Bakker AH, Janssen E, Bijlsma JWJ. Intrusiveness of rheumatoid arthritis on sexuality in male and female patients living with a spouse. Arthritis Rheumatol [Internet]. 1996;9(2):120-5.

375 6. Kurizky PS, Mota LM. Sexual dysfunction in patients with psoriasis and psoriatic arthritis - a systematic review. Rev Bras Reumatol Engl Ed [Internet]. 2012;52(6):943-8. 7. El Miedany Y, El Gaafary M, El Aroussy N, Youssef S, Ahmed I. Sexual dysfunction in rheumatoid arthritis patients: arthritis and beyond. Clin Rheumatol [Internet]. 2012;31(4):601-6.

8. Hill J, Bird H, Thorpe R. Effects of rheumatoid arthritis on sexual activity and relationships. Rheumatol. 2003;42(2):280-6.

9. Majerovitz S, Revenson TA. Sexuality and rheumatic disease: The significance of gender. Arthritis Care Res (Hoboken). 1994;7(1):29-34.

10. van Berlo WTM, Vennix P, Rasker JJ, van Rijswijk MH, Taal E, Weijmar schulz WCM, et al. Rheumatic diseases and sexuality: a review of the literature. Rheumatol Europe. 1999;28(3):113-7. 
11. Ostlund G, Björk M, Valtersson E, Sverker A. Intimate Relationships as Perceived by Patients with Early Rheumatoid Arthritis: A Qualitative Interview Study (The Swedish Tira Study). Ann Rheum Dis [Internet]. 2014;73(Suppl 2):1220.

12. Matheson L, Harcourt D, Hewlett S. Your whole life, your whole world, it changes': Partners' experiences of living with rheumatoid arthritis. Musculoskeletal Care [Internet]. 2010;8:46-54.

13. Yoshino S, Uchida S. Sexual problems of women with rheumatoid arthritis. Arch Phys Med Rehabil [Internet]. 1981;62:122-3.

14. Blake DJ. Sexual disorders among patients with arthritis. Intern Med Rev (Wash D C) [Internal]. 1988;9:173-82.

15. Cohen M. Sexuality and the arthritic patient-how well are we doing? J Rheumatol [Internet]. 1987 14:403-4.

16. Abdel-Nasser A, Ali E. Determinants of sexual disability and dissatisfaction in female patients with rheumatoid arthritis. Clin Rheumatol [Internet]. 2006;25(6):822-30.

17. Blake DJ, Maisiak R, Alarcon GS, Holley HL, Brown S. Sexual quality of life of patients with arthritis compared to arthritis-free controls. J Rheumatol [Internet]. 1987;14:570-6.

18. Rkain H, Allali F, Jroundi I, Hajjaj-Hassouni N. Socioeconomic impact of rheumatoid arthritis in Morocco. Joint Bone Spine. 2006;73(3):278-83.

19. van Berlo WT, van de Wiel HB, Taal E, Rasker JJ, Weijmar Schultz WC, van Rijswijk MH. Sexual functioning of people with rheumatoid arthritis: a multicenter study. Clin Rheumatol [Internet]. 2007;26(1):30-8.

20. Briggs AM, Jordan JE, Ackerman IN, Van Doornum S. Establishing cross-discipline consensus on contraception, pregnancy and breast feeding-related educational messages and clinical practices to support women with rheumatoid arthritis: an Australian Delphi study. BMJ [Internet]. 2016;6(9).

21. Özgül A, Peker F, Taskaynatan MA, Tan AK, Dinçer K, Kalyon TA. Effect of ankylosing spondylitis on health-related quality of life and different aspects of social life in young patients. Clin Rheumatol [Internet]. 2006;25:168-74.

22. Sariyildiz MA, Batmaz I, Dilek B, Bozkurt M, Karakoc M, Çevik R, et al. The impact of ankylosing spondylitis on female sexual functions. Int J Impot Res [Internet]. 2013;25:104-8. 23. Zautra AJ, Hoffman JM, Matt KS, Yocum D, Potter PT, Castro WL, et al. An examination of individual differences in the relationship between interpersonal stress and 
disease activity among women with rheumatoid arthritis. Arthritis Care Res (Hoboken) [Internet]. 1998;11:271-9.

24. Ackerman IN, Jordan JE, Van Doornum S, Ricardo M, Briggs AM. Understanding the information needs of women with rheumatoid arthritis concerning pregnancy, post-natal care and early parenting: A mixed-methods study. BMC Musculoskelet Disord [Internet]. 2015 [cited 2018 March 29];16:194.

25. Baldursson $\mathrm{H}$, Brattstrom $\mathrm{H}$. Sexual difficulties and total hip replacement in rheumatoid arthritis. Scand J Rheumatol [Internet]. 1979;8:214-16.

26. Pouchot J, Le Parc JM, Queffelec L, Sichere P, Flinois A. Perceptions in 7700 patients with rheumatoid arthritis compared to their families and physicians. Joint Bone Spine [Internet]. 2007;74:622-6.

27. Josefsson KA, Gard G. Sexual health in patients with rheumatoid arthritis: experiences, needs and communication with health care professionals. Musculoskeletal Care. 2012;10(2):76-89.

28. Molina-Leyva A, Jiménez-Moleón JJ, Naranjo-Sintes R, Ruiz-Carrascosa JC. Sexual dysfunction in psoriasis: a systematic review. J Eur Acad Dermatol Venereol [Internet]. 2015;29:649-55.

29. Areskoug-Josefsson K, Oberg U. A literature review of the sexual health of women with rheumatoid arthritis. Musculoskeletal Care. 2009;7(4):219-26.

30. Al-Ezzi MY, Pathak N, Tappuni AR, Khan KS. Primary Sjogren's syndrome impact on smell, taste, sexuality and quality of life in female patients: A systematic review and metaanalysis. Mod Rheumatol. 2017;27(4):623-9.

31. Fan D, Liu L, Ding N, Liu S, Hu Y, Cai G, et al. Male sexual dysfunction and ankylosing spondylitis: a systematic review and metaanalysis. J Rheumatol. 2015;42(2):252-7.

32. Knafo R, Thombs BD, Jewett L, Hudson M, Wigley F, Haythornthwaite JA. (Not) talking about sex: a systematic comparison of sexual impairment in women with systemic sclerosis and other chronic disease samples. Rheumatol. 2009;48(10):1300-3.

33. Lotfi MA, Varga J, Hirsch IH. Erectile dysfunction in systemic sclerosis. J Urology. 1995;45(5):879-81.

34. Parke AL. Sjogren's syndrome: a women's health problem. J Rheumatol Suppl. 2000;61:4-5. 
35. Rosenbaum TY. Musculoskeletal pain and sexual function in women. J Sex Med [Internet]. 2010;7(2 Pt 1):645-53.

36. Vinet E, Pineau C, Gordon C, Clarke AE, Bernatsky S. Systemic lupus erythematosus in women: impact on family size. Arthritis Rheumatol [Internet]. 2008;59(11):1656-60. 37. Yin R, Xu B, Li L, Fu T, Zhang L, Zhang $Q$, et al. The impact of systemic lupus erythematosus on women's sexual functioning: A systematic review and meta-analysis. Med (United States). 2017;96 (27) (no pagination)(e7162).

38. Zahedi Niaki O, Bernatsky S, Vinet E. Reproductive Issues in Males with SLE. Curr Treatm Opt Rheumatol. 2017;3(3):173-80.

39. Zhang Q, Zhou C, Chen H, Zhao Q, Li L, Cui Y, et al. Rheumatoid arthritis is associated with negatively variable impacts on domains of female sexual function: evidence from a systematic review and meta-analysis. Psychol Health Med. 2018;23(1):114-25.

40. Gossec L, Berenbaum F, Chauvin P, Lamiraud K, Russo-Marie F, Joubert JM, et al. Reporting of patient-perceived impact of rheumatoid arthritis and axial spondyloarthritis over 10 years: A systematic literature review. Rheumatol (United Kingdom). 2014;53(7):1274-81.

41. Gudu T, Kiltz U, de Wit M, Kvien TK, Gossec L. Mapping the effect of psoriatic arthritis using the International Classification of Functioning, Disability and Health. J Rheumatol. 2017;44(2):193-200.

42. Hill J. The impact of rheumatoid arthritis on patients' sex lives. Nurs Times Nurs Homes. 2004;100(20):34-5.

43. Liu YF, Dong H, Chen Z, Wang Y, Tu SH. Impact of ankylosing spondylitis on sexual function: A systematic review and meta analysis. Exp Ther Med. 2015;9(4):1501-7. 44. Nakayama A, Tunnicliffe DJ, Thakkar V, Singh-Grewal D, O'Neill S, Craig JC, et al. Patients' Perspectives and Experiences Living with Systemic Sclerosis: A systematic review and thematic synthesis of qualitative studies. J Rheumatol. 2016;43(7):1363-75.

45. Saad S, Behrendt AE. Scleroderma and sexuality. J Sex Med [Internet]. 1996;33(3):215-20.

46. Shah AA, Wigley FM. Often forgotten manifestations of systemic sclerosis. Rheum Dis Clin North Am. 2008;34(1):221-38; ix. 
47. Sutanto B, Singh-Grewal D, McNeil HP, O'Neill S, Craig JC, Jones J, et al. Experiences and perspectives of adults living with systemic lupus erythematosus: Thematic synthesis of qualitative studies. Arthritis Care Res (Hoboken). 2013;65(11):1752-65.

48. Taylor PC, Moore A, Vasilescu R, Alvir J, Tarallo M. A structured literature review of the burden of illness and unmet needs in patients with rheumatoid arthritis: a current perspective. Rheumatol Int. 2016;36(5):685-95.

49. Tristano AG. Impact of rheumatoid arthritis on sexual function. World J Orthop. 2014;5(2):107-11.

50. Tristano AG. The impact of rheumatic diseases on sexual function. Rheumatol Int. 2009;29(8):853-60.

51. Zhao S, LiE, Wang J, Luo L, Luo J, Zhao Z. Rheumatoid Arthritis and Risk of Sexual Dysfunction: A Systematic Review and Metaanalysis. J Rheumatol. 2018;45(10):1375-82. 52. Østensen M. New insights into sexual functioning and fertility in rheumatic diseases. Best Pract Res Clin Rheumatol. 2004;18(2):219-32.

53. Panush RS, Mihailescu GD, Gornisiewicz MT, Sutaria SH, Wallace DJ. Sex and arthritis. Bull Rheum Dis. 2000;49(7):1-4.

54. Berg KH, Rohde G, Prøven A, Almås E, Benestad EEP, Østensen M, et al. Exploring the relationship between demographic and disease-related variables and perceived effect of health status on sexual activity in patients with axial spondyloarthritis: associations found only with non-disease variables. Scand J Rheumatol [Internet]. 2017;46(6):461-7. 55. Chaigne B, Finckh A, Alpizar-Rodriguez D, Courvoisier D, Ribi C, Chizzolini C. Differential impact of systemic lupus erythematosus and rheumatoid arthritis on healthrelated quality of life. Qual Life Res [Internet]. 2017;26(7):1767-75.

56. Miedany Y, Gaafary M, Aroussy N, Youssef S, Ahmed I. Sexual dysfunction in rheumatoid arthritis patients: arthritis and beyond. Int J Rheum Dis [Internet]. 2012;31(4):601-6.

57. Josefsson KA, Gard G. Sexual health in patients with rheumatoid arthritis: experiences, needs and communication with health care professionals. Musculoskeletal Care [Internet]. 2012;10(2):76.

58. Josefsson KA, Gard G. Women's experiences of sexual health when living with Rheumatoid Arthritis - an explorative qualitative study. BMC Musculoskelet Disord [Internet]. 2010;11(1):240. 
59. Akkuş $Y$, Nakas D, Kalyoncu U. Factors Affecting the Sexual Satisfaction of Patients with Rheumatoid Arthritis and Ankylosing Spondylitis. Sex Disabil [Internet]. 2010;28(4):22332.

60. Seawell AH, Danoff-Burg S. Body image and sexuality in women with and without systemic lupus erythematosus. Sex Roles. 2005;53(11-12):865-76.

61. Dincer U, Cakar E, Kiralp MZ, Dursun H. Assessment of sexual dysfunction in male patients with Ankylosing Spondylitis. Rheumatol Int. 2007;27(6):561-6.

62. Healey EL, Haywood KL, Jordan KP, Garratt AM, Ryan S, Packham JC. Ankylosing spondylitis and its impact on sexual relationships. Rheumatol. 2009;48(11):1378-81. 63. Impens AJ, Rothman J, Schiopu E, Cole JC, Dang J, Gendrano N, et al. Sexual activity and functioning in female scleroderma patients. Clin Exp Rheumatol. 2009;27(3 Suppl 54):38-43.

64. Bal S, Bal K, Turan Y, Deniz G, Gurgan A, Berkit IK, et al. Sexual functions in ankylosing spondylitis. Rheumatol Int. 2011;31(7):889-94.

65. Ozkorumak E, Karkucak M, Civil F, Tiryaki A, Ozden G. Sexual function in male patients with ankylosing spondylitis. Int J Impot Res. 2011;23(6):262-7.

66. Gallinaro AL, Akagawa LL, Otuzi MH, Sampaio-Barros PD, Goncalves CR. Sexual activity in ankylosing spondylitis. Rev Bras Reumatol Engl Ed [Internet]. 2012;52(6):887-91.

67. Rezvani A, Ok S, Demir SE. Assessment of sexual functions in male patients with ankylosing spondylitis compared with healthy controls. Arch Rheumatol. 2012;27(4):233-40. 68. Aras H, Aras B, Icagasioglu A, Yumusakhuylu Y, Kemahli E, Haliloglu S, et al. Sexual dysfunction in women with rheumatoid arthritis. Med Glas (Zenica). 2013;10(2):327-31. 69. Bongi SM, Del Rosso A, Mikhaylova S, Baccini M, Cerinic MM. Sexual function In Italian women with systemic sclerosis is affected by disease-related and psychological concerns. J Rheumatol. 2013;40(10):1697-705.

70. Daleboudt GMN, Broadbent E, McQueen F, Kaptein AA. The impact of illness perceptions on sexual functioning in patients with systemic lupus erythematosus. J Psychosom Res. 2013;74(3):260-4.

71. Demir SE, Rezvani A, Ok S. Assessment of sexual functions in female patients with ankylosing spondylitis compared with healthy controls. Rheumatol Int. 2013;33(1):57-63. 
543 Fernandez R, Camps Garcia MT, et al. Impaired sexual function in women with systemic

544 lupus erythematosus: a cross-sectional study. Lupus. 2013;22(10):987-95.

545 73. Rostom S, Mengat M, Mawani N, Jinane H, Bahiri R, Hajjaj-Hassouni N. Sexual activity 546 in Moroccan men with ankylosing spondylitis. Rheumatol Int. 2013;33(6):1469-74.

547 74. Aguiar R, Ambrosio C, Cunha I, Barcelos A. Sexuality in spondyloarthritis - the impact 548 of the disease. Acta Reumatol Port. 2014;39(2):152-7.

549 75. Coskun B, Coskun BN, Atis G, Ergenekon E, Dilek K. Evaluation of sexual function in 550 women with rheumatoid arthritis. J Urology. 2014;10(4):1081-7.

551 76. Frikha F, Masmoudi J, Saidi N, Bahloul Z. Sexual dysfunction in married women with 552 Systemic Sclerosis. Pan Afr Med J. 2014;17:82.

553 77. Oksel E, Gunduzoglu NC. Investigation of life experiences of women with 554 scleroderma. Sex Disabil [Internet]. 2014;32(1):15-21.

555 78. ÖNem R, ÇElik S, ÖNcÜ J, Tankaya O, Kolat U, Sungu DaniŞMant B, et al. Assessment 556 of marital adjustment and sexuality in women with rheumatoid arthritis. Arch Rheumatol. 557 2014;29(4):280-8.

558 79. Rosato E, Rossi C, Molinaro I, Digiulio MA, Trombetta AC, Marra AM, et al. Sexual 559 distress, sexual dysfunction and relationship quality in women with systemic sclerosis: 560 Correlation with clinical variables. Int J Immunopathol Pharmacol. 2014;27(2):279-85.

561 80. Bagcivan G, Cinar FI, Cinarb M, Oflaz F, Uzun S, Pay S. Living with pain in ankylosing 562 spondylitis: a qualitative study. Contemp Nurse. 2015;51(2-3):135-47.

563 81. Dhakad U, Singh BP, Das SK, Wakhlu A, Kumar P, Srivastava D, et al. Sexual 564 dysfunctions and lower urinary tract symptoms in ankylosing spondylitis. Int J Rheum Dis 565 [Internet]. 2015;18(8):866-72.

566 82. Hari A, Rostom S, Lahlou R, Bahiri R, Hajjaj-Hassouni N. Sexual function in Moroccan 567 women with rheumatoid arthritis and its relationship with disease activity. Clin Rheumatol 568 [Internet]. 2015;34(6):1047-51.

569 83. Östlund G, Björk M, Valtersson E, Sverker A. Lived experiences of sex life difficulties 570 in men and women with early RA - The Swedish TIRA Project. Musculoskeletal Care. $571 \quad 2015 ; 13(4): 248-57$.

572 84. Saadat SH, Ramezani A, Ahmadi K. Sexual self-concept and general health in 573 rheumatoid arthritis patients. Iran Red Crescent Med J. 2015;17(10):e19005. 
85. Abda E, Selim Z, Teleb S, Zaghira M, Fawzy M, Hamed S. Sexual function in females with rheumatoid arthritis: relationship with physical and psychosocial states. Arch Rheumatol. 2016;31(3):239-47.

86. Akkurt HE, Yilmaz H, Yilmaz S, Parlak L, Ordahan B, Salli A. Evaluation of sexual dysfunction in females with ankylosing spondylitis. Arch Rheumatol. 2016;31(1):41-7. 87. Priori R, Minniti A, Derme M, Antonazzo B, Brancatisano F, Ghirini S, et al. Quality of sexual life in women with primary sjogren syndrome. J Rheumatol. 2015;42(8):1427-31.

88. Khnaba D, Rostom S, Lahlou R, Bahiri R, Abouqal R, Hajjaj-Hassouni N. Sexual dysfunction and its determinants in Moroccan women with rheumatoid arthritis. Pan Afr Med J. 2016;24:16.

89. Pendeke TF, Williamson IR. "Half the Man I Was": Exploring accounts of emasculation and estrangement amongst British men living with systemic lupus erythematosus. Int J Mens Health. 2016;15(2):165-73.

90. Sanchez K, Denys P, Giuliano F, Palazzo C, Berezne A, Abid H, et al. Systemic sclerosis: Sexual dysfunction and lower urinary tract symptoms in 73 patients. Presse Med. 2016;45(4 Pt 1):e79-89.

91. Isik H, Isik M, Aynioglu O, Karcaaltincaba D, Sahbaz A, Beyazcicek T, et al. Are the women with Sjogren's Syndrome satisfied with their sexual activity? Rev Bras Reumatol Engl Ed [Internet]. 2017;57(3):210-6.

92. Santana T, Skare T, Delboni VS, Simione J, Campos APB, Nisihara R. Erectile dysfunction in ankylosing spondylitis patients. International Braz J Urol. 2017;43(4):730-5.

93. Dorner TE, Berner C, Haider S, Grabovac I, Lamprecht T, Fenzl KH, et al. Sexual health in patients with rheumatoid arthritis and the association between physical fitness and sexual function: a cross-sectional study. Rheumatol Int. 2018;11:11.

94. Helland Y, Dagfinrud H, Kvien TK. Perceived influence of health status on sexual activity in RA patients: associations with demographic and disease-related variables. Scand J Rheumatol [Internet]. 2008;37(3):194-9.

95. Helland Y, Kjeken I, Steen E, Kvien TK, Hauge MI, Dagfinrud H. Rheumatic diseases and sexuality: Disease impact and self-management strategies. Arthritis Care Res (Hoboken). 2011;63(5):743-50. 
96. Kobelt G, Texier-Richard B, Mimoun S, Woronoff AS, Bertholon DR, Perdriger A, et al. Rheumatoid arthritis and sexuality: a patient survey in France. BMC Musculoskelet Disord [Internet]. 2012;13:170.

97. Levis B, Burri A, Hudson M, Baron M, Thombs BD. Sexual activity and impairment in women with systemic sclerosis compared to women from a general population sample. PLoS ONE. 2012;7(12) (no pagination)(e52129).

98. Schouffoer AA, van der Marel J, Ter Kuile MM, Weijenborg PT, Voskuyl A, Vliet Vlieland CW, et al. Impaired sexual function in women with systemic sclerosis: a crosssectional study. Arthritis Rheumatol [Internet]. 2009;61(11):1601-8.

99. Tseng JC, Lu LY, Hu JC, Wang LF, Yen L, Wu HC, et al. The impact of systemic lupus erythematosus on women's sexual functioning. J Sex Med [Internet]. 2011;8(12):3389-97. 100. Yilmaz H, Polat HA, Yilmaz SD, Erkin G, Kucuksen S, Salli A, et al. Evaluation of sexual dysfunction in women with rheumatoid arthritis: a controlled study. J Sex Med [Internet]. 2012;9(10):2664-70.

101. Ugurlu G, Erten S, Ugurlu M, Caykoylu A, Altunoğlu A. Sexual dysfunction in female patients with Primary Sjögren's Syndrome and effects of depression: cross-sectional study. Sex Disabil [Internet]. 2014;32(2):197-204.

102. van Nimwegen JF, Arends S, van Zuiden GS, Vissink A, Kroese FG, Bootsma H. The impact of primary Sjogren's syndrome on female sexual function. Rheumatol. 2015;54(7):1286-93.

103. Hoy D, Brooks P, Woolf A, Blyth F, March L, Bain C, et al. Assessing risk of bias in prevalence studies: modification of an existing tool and evidence of interrater agreement. Journal of Clinical Epidemiology. 2012;65(9):934-9.

104. Critical Appraisal Skills Programme. CASP (Qualitative) Checklist UK: CASP; 2018 [Available from: https://casp-uk.net/casp-tools-checklists/.

105. Chou L, Shamdasani P, Briggs A, Cicuttini F, Sullivan K, Seneviwickrama K, et al. Systematic scoping review of patients' perceived needs of health services for osteoporosis. With other metabolic bone diseases. 2017;28(11):3077-98.

106. Chou L, Ranger TA, Peiris W, Cicuttini FM, Urquhart DM, Sullivan K, et al. Patients' perceived needs of health care providers for low back pain management: a systematic scoping review. Spine J. 2018;18(4):691-711. 
107. Chou L, Ellis L, Papandony M, Seneviwickrama K, Cicuttini F, Sullivan K, et al. Patients' perceived needs of osteoarthritis health information: A systematic scoping review. PLoS One. 2018;13(4).

108. Chou L, Cicuttini FM, Urquhart DM, Anthony SN, Sullivan K, Seneviwickrama M, et al. People with low back pain perceive needs for non-biomedical services in workplace, financial, social and household domains: a systematic review. J Physiother. 2018;64(2):7483.

109. Segan JD, Briggs AM, Chou L, Connelly KL, Seneviwickrama M, Sullivan K, et al. Patient-perceived health service needs in inflammatory arthritis: A systematic scoping review. Semin Arthritis Rheum. 2018;47(6):765-77.

110. Papandony MC, Chou L, Seneviwickrama M, Cicuttini FM, Lasserre K, Teichtahl AJ, et al. Patients' perceived health service needs for osteoarthritis $(O A)$ care: a scoping systematic review. Osteoarthritis Cartilage. 2017;25(7):1010-25.

111. Hannes K, Macaitis K. A move to more systematic and transparent approaches in qualitative evidence synthesis: update on a review of published papers. Qual Res. 2012;12(4):402-42.

112. Thomas J, Harden A. Methods for the thematic synthesis of qualitative research in systematic reviews. BMC Med Res Methodol. 2008;8(1):45.

113. Barnett-Page E, Thomas J. Methods for the synthesis of qualitative research: a critical review. BMC Med Res Methodol. 2009;9(1):59.

114. Lewin S, Glenton C, Munthe-Kaas H, Carlsen B, Colvin CJ, Gülmezoglu M, et al. Using qualitative evidence in decision making for health and social interventions: An approach to assess confidence in findings from qualitative evidence syntheses (GRADE-CERQual). PLoS ONE. 2015;12(10):e1001895.

115. Bhadauria S, Moser DK, Clements PJ, Singh RR, Lachenbruch PA, Pitkin RM, et al. Genital tract abnormalities and female sexual function impairment in systemic sclerosis. Am J Obstet Gynecol.1995;172(2 Pt 1):580-7.

116. Druley JA, Stephens MA, Coyne JC. Emotional and physical intimacy in coping with lupus: women's dilemmas of disclosure and approach. Health Psychol Open. 1997;16(6):506-14.

117. Foocharoen C, Tyndall A, Hachulla E, Rosato E, Allanore Y, Farge-Bancel D, et al. Erectile dysfunction is frequent in systemic sclerosis and associated with severe disease. A 
667

668

669

670

671

672

673

674

675

676

677

678

679

680

681

682

683

684

685

686

687

688

689

690

691

692

693

694

695

696

697

study of the EULAR Scleroderma Trial and Research (EUSTAR) group. Arthritis Res Ther. 2012:R37.

118. Onem R, Cellk S, Oncu J, Tankaya O, Kolat U, Sungu Danismant B, et al. Assessment of Marital Adjustment and Sexuality in Women With Rheumatoid Arthritis. Arch Rheumatol. $2014 ; 29(4): 280-8$.

119. Ozgul A, Peker F, Taskaynatan MA, Tan AK, Dincer K, Kalyon TA. Effect of ankylosing spondylitis on health-related quality of life and different aspects of social life in young patients. Clin Rheumatol [Internet]. 2006;25(2):168-74.

120. Pirildar T, Muezzinoglu T, Pirildar S. Sexual function in ankylosing spondylitis: a study of 65 men. J Clin Urol. 2004;171(4):1598-600.

121. Sariyildiz MA, Batmaz I, Dilek B, Inanir A, Bez Y, Tahtasiz M, et al. Relationship of the sexual functions with the clinical parameters, radiological scores and the quality of life in male patients with ankylosing spondylitis. Rheumatol Int. 2013;33(3):623-9.

122. Ostlund G, Bjork M, Valtersson E, Sverker A. Lived Experiences of Sex Life Difficulties in Men and Women with Early RA - The Swedish TIRA Project. Musculoskeletal Care. 2015;13(4):248-57.

123. Rosen C, Brown J, Heiman S, Leiblum C, Meston R, Shabsigh D. The Female Sexual Function Index (FSFI): A multidimensional self-report instrument for the assessment of female sexual function. J Sex Marital Ther. 2000;26(2):191-208.

124. Rosen RC, Cappelleri J, Smith M, Lipsky J, Peña B. Development and evaluation of an abridged, 5-item version of the International Index of Erectile Function (IIEF-5) as a diagnostic tool for erectile dysfunction. Int J Impot Res. 2000;11(6):319.

125. Rosato E, Barbano B, Gigante A, Aversa A, Cianci R, Molinaro I, et al. Erectile dysfunction, endothelium dysfunction, and microvascular damage in patients with systemic sclerosis.J Sex Med [Internet]. 2013;10(5):1380-8.

126. Druley JA. Couples coping with wives' systemic lupus erythematosus. Diss Abstr Int. 1996;56(10-B):5832.

127. Weber MF, Smith DP, O'Connell DL, Patel MI, de Souza PL, Sitas F, et al. Risk factors for erectile dysfunction in a cohort of 108477 Australian men. Med J Aust. 2013;199(2):107. 128. Litwin M, Nied R, Dhanani N. Health-related quality of life in men with erectile dysfunction. J Gen Intern Med. 1998;13(3):159-66. 
702

703

704

705

706

707

708

709

710

711

712

713

714

715

716

717

718

719

720

721

129. Abdel-Nasser AM, Ali El. Determinants of sexual disability and dissatisfaction in female patients with rheumatoid arthritis. Clin Rheumatol [Internet]. 2006;25(6):822-30. 130. Ryan S, Dawes P, Mayer B. Does inflammatory arthritis affect sexuality? Br J Rheumatol. 1996;35(Suppl 2):19.

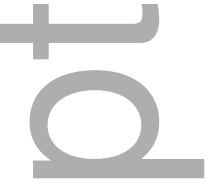

\section{Figure Legends}

Figure 1: PRISMA flow chart of included studies.

Figure 2: $\quad$ Mean Female Sexual Function Index (FSFI) scores and standard deviations (error bars). Studies are grouped by type of IA. Sexual dysfunction is indicated by FSFI score $\leq 26.5$ (123), indicated by the solid horizontal line on the graph. Abbreviations: AS: Ankylosing Spondylosis; SS: Sjogren's Syndrome; RA: Rheumatoid Arthritis; SLE: Systemic Lupus Erythematous; SSc: Systemic Sclerosis *van Nimwegen et al. (2015) (102) did not report standard deviations.

Figure 3: Mean International Index of Erectile Function (IIEF) scores and standard deviations (error bars). Studies are grouped by type of IA. Sexual dysfunction is indicated by IIEF score $\leq 25(43,124)$, indicated by the solid horizontal line on the graph.

Abbreviations: AS: Ankylosing Spondylosis; RA: Rheumatoid Arthritis; SSc: Systemic Sclerosis.

*As Rezvani et al. (2012) (67) did not report mean scores or standard deviations, median scores for this study are shown instead. 
Table 1: Summary of included studies

\begin{tabular}{|c|c|c|c|c|c|c|c|}
\hline Study & $\begin{array}{l}\text { Country } \\
\text { where data } \\
\text { collected }\end{array}$ & Study Design & Setting & $\begin{array}{c}\text { IA group } \\
\mathrm{N} \text {, gender (\%), mean (SD) age } \\
\text { in years unless stated } \\
\text { otherwise }\end{array}$ & $\begin{array}{c}\text { Type of IA } \\
\text { N (\%) }\end{array}$ & $\begin{array}{c}\text { IA disease } \\
\text { duration, mean } \\
\text { (SD) years } \\
\text { unless stated } \\
\text { otherwise }\end{array}$ & $\begin{array}{c}\text { Control group } \\
\mathrm{N} \text {, gender (\%), mean (SD) age in } \\
\text { years unless stated otherwise }\end{array}$ \\
\hline $\begin{array}{c}\text { Abda et al., } 2 \\
\text { (85) }\end{array}$ & sypt & $\begin{array}{l}\text { Quantitative cross-sectional } \\
\text { controlled cohort survey }\end{array}$ & $\begin{array}{l}\text { Department of rheumatology } \\
\text { and rehabilitation, university } \\
\text { hospital }\end{array}$ & 200, female (100), $44.2(9.1)$ & RA: 200 (100) & $5.8(4.1)$ & 100 , female (100), $42.5(6.3)$ \\
\hline $\begin{array}{l}\text { Aguiar et al., } \\
2014(74)\end{array}$ & ot stated & $\begin{array}{l}\text { Quantitative cross-sectional } \\
\text { single group survey }\end{array}$ & $\begin{array}{l}\text { Outpatient rheumatology clinic } \\
\text { in private hospital setting }\end{array}$ & 76, female $(50), 46.1(12.1)$ & $\begin{array}{l}\text { PsA: } 31 \text { (41); } \\
\text { AS: } 30(39) ; \\
\text { undifferentiat } \\
\text { ed SpA: } 9 \\
\text { (12); } \\
\text { IBD: } 6 \text { (8) }\end{array}$ & $12.2(10.3)$ & N/A \\
\hline $\begin{array}{l}\text { Akkurt et al., } \\
2016(86)\end{array}$ & urkey & $\begin{array}{l}\text { Quantitative cross-sectional } \\
\text { controlled cohort survey }\end{array}$ & Not stated & 54 , female (100), $39.3(8.6)$ & IA: $100(100)$ & $8.5(5.1)$ & 56 , female (100), $37.6(9.6)$ \\
\hline $\begin{array}{c}\text { Aras et al., } 2013 \\
(68)\end{array}$ & urkey & $\begin{array}{l}\text { Quantitative cross-sectional } \\
\text { controlled cohort survey }\end{array}$ & $\begin{array}{l}\text { Department of physical medicine } \\
\text { and rehabilitation in a tertiary } \\
\text { hospital setting }\end{array}$ & 104 , female $(100), 48.6(8.6)$ & RA: 104 (100) & $\begin{array}{l}9.3(S D \text { not } \\
\text { reported) }\end{array}$ & 82, female (100), $46.7(7.6)$ \\
\hline $\begin{array}{l}\text { Bagcivan et al., } \\
2015(80)\end{array}$ & Turkey & $\begin{array}{l}\text { Qualitative study (semi - } \\
\text { structured interviews) }\end{array}$ & $\begin{array}{l}\text { Rheumatology outpatient clinic, } \\
\text { university hospital }\end{array}$ & 23, female (30), $29.6(6.0)$ & AS: $23(100)$ & $5.4(3.5)$ & N/A \\
\hline $\begin{array}{l}\text { Bal et al., } 2011 \\
\text { (64) }\end{array}$ & Not stated & $\begin{array}{l}\text { Quantitative cross-sectional } \\
\text { controlled cohort survey }\end{array}$ & Not stated & 37, male (100), $42.8(10.8)$ & AS: $37(100)$ & $10(9)$ & 67 , male (100), $43.6(5.9)$ \\
\hline $\begin{array}{c}\text { Bhadauria et al., } \\
1995 \text { (115) }\end{array}$ & $\begin{array}{l}\text { United States } \\
\text { of America }\end{array}$ & $\begin{array}{l}\text { Quantitative cross-sectional } \\
\text { controlled cohort survey }\end{array}$ & $\begin{array}{l}\text { Private practice of } \\
\text { rheumatologist in private } \\
\text { hospital setting }\end{array}$ & 60 , female (100), $50.5(12.0)$ & SSc: 60 (100) & $10.9(7.6)$ & 23, female (100), $46.0(12.3)$ \\
\hline
\end{tabular}

This article is protected by copyright. All rights reserved 


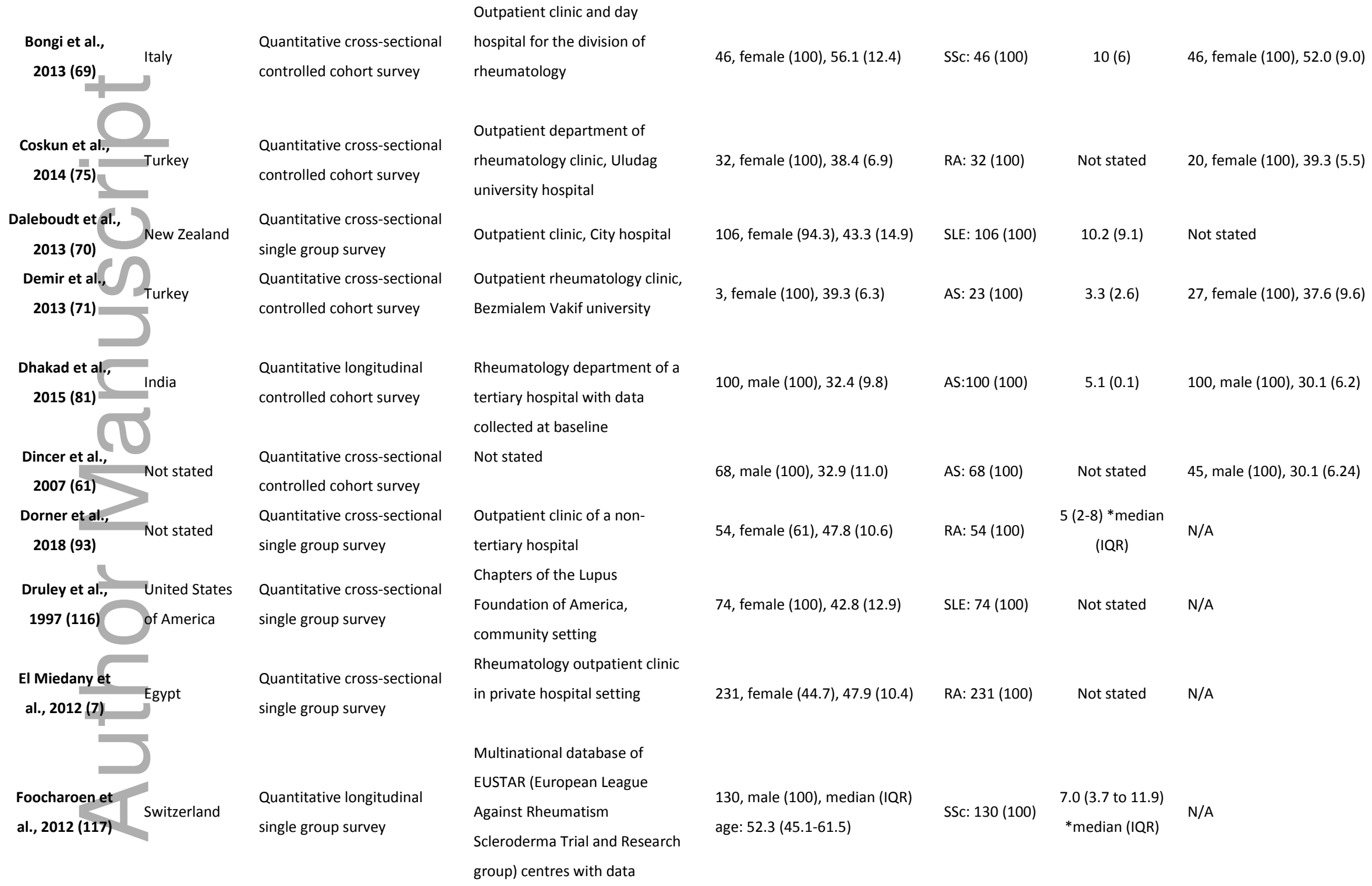

This article is protected by copyright. All rights reserved 


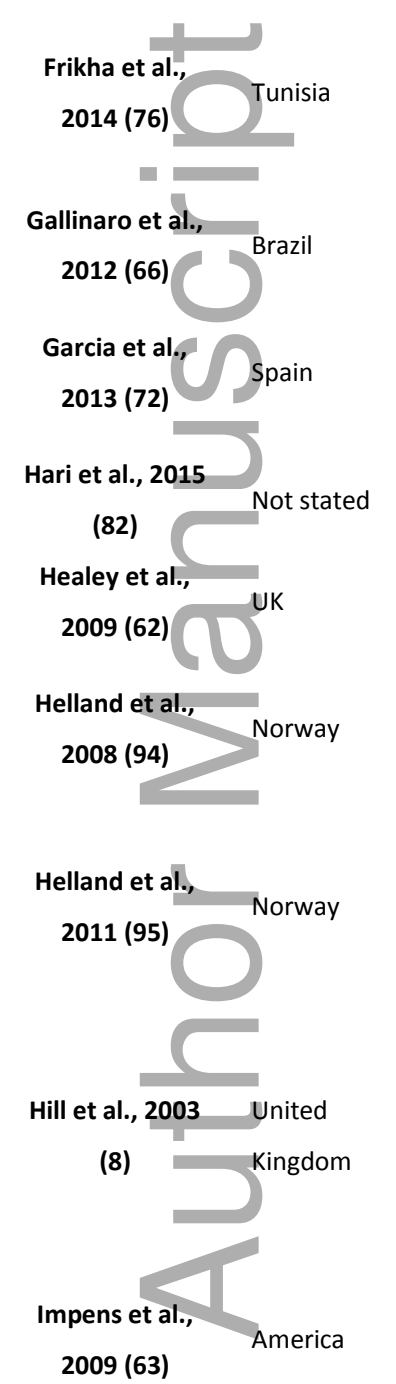

Quantitative longitudinal

single group survey

Quantitative cross-sectional

controlled cohort survey

Quantitative cross-sectiona

controlled cohort survey

Quantitative cross-sectional

controlled cohort survey

Quantitative cross-sectional

single group survey

Quantitative cross-sectional

single group survey

Qualitative study (interviews and focus groups)

Mixed study (quantitative,

cross-sectional single group

survey and free text

questionnaires

Quantitative cross-sectiona

single group survey
Department of internal medicine

in Sfax-Tunisia university hospital

with data collected at baseline

Outpatient SpA clinic, university hospital

Systemic autoimmune diseases

unit of Hospital of San Cecilio of Granada

Not stated

Ten site specific NHS (National

Health Services) trust hospitals

Postal questionnaires to patients

in ORAR (Oslo Rheumatoid

Arthritis Register)

Rheumatology clinic, tertiary

hospital

23, female (43) 44.2 (10.5)

AS: 7 (30);

PsA: 4 (17);

JIA: 1 (4)

Two consecutive rheumatology

outpatient clinics at a large

teaching hospital

57 , female (82), 58, age range:

36-75

RA: 57 (100)

male: 1.5

(3.0-6.3)

Male: 5 (3.2-

6.3)

*median (IQR)

Outpatient clinic of the

scleroderma program of a

university hospital
101, female (100), 47.5 (no

range/SD/IQR) 


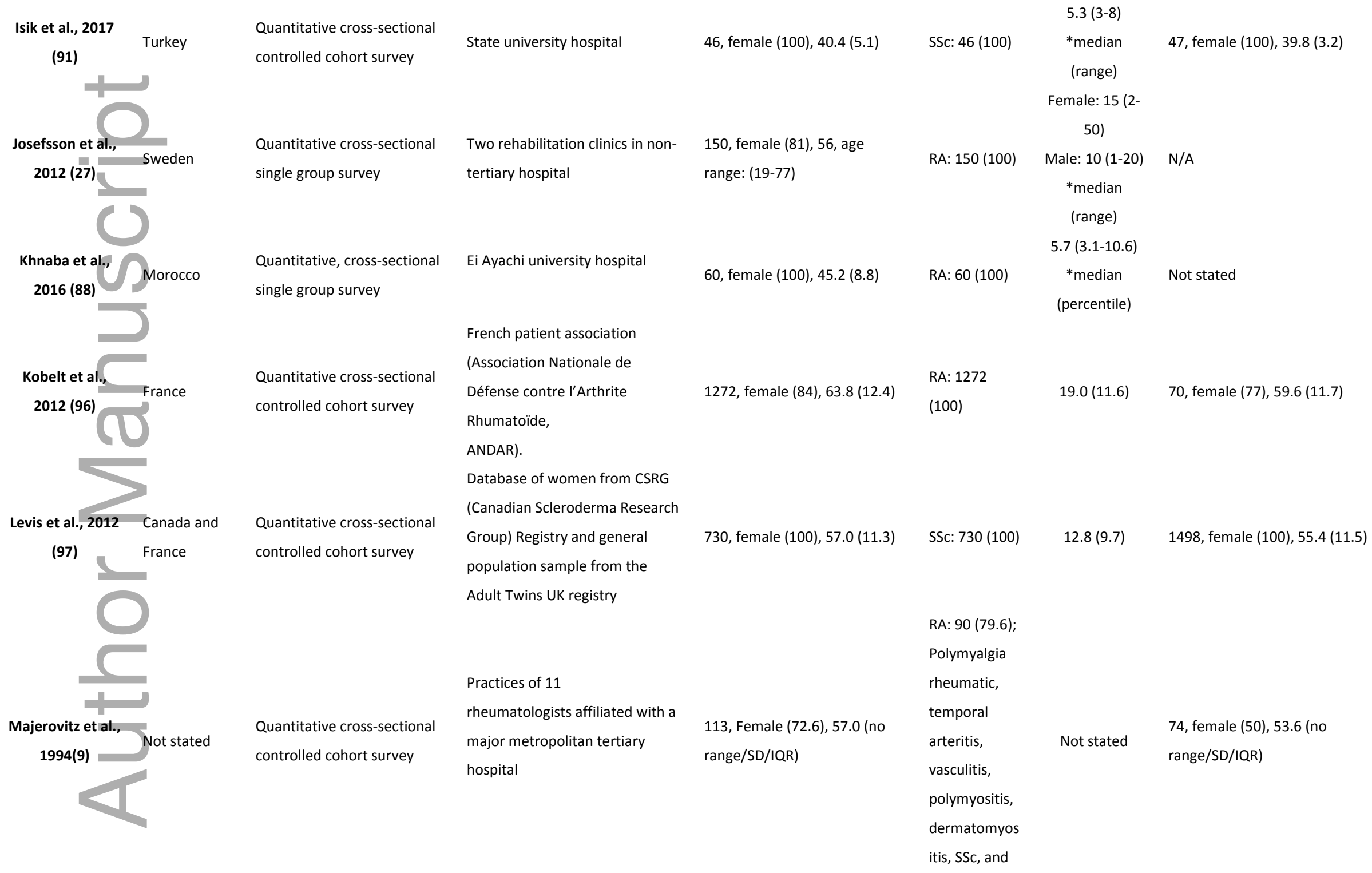

This article is protected by copyright. All rights reserved 


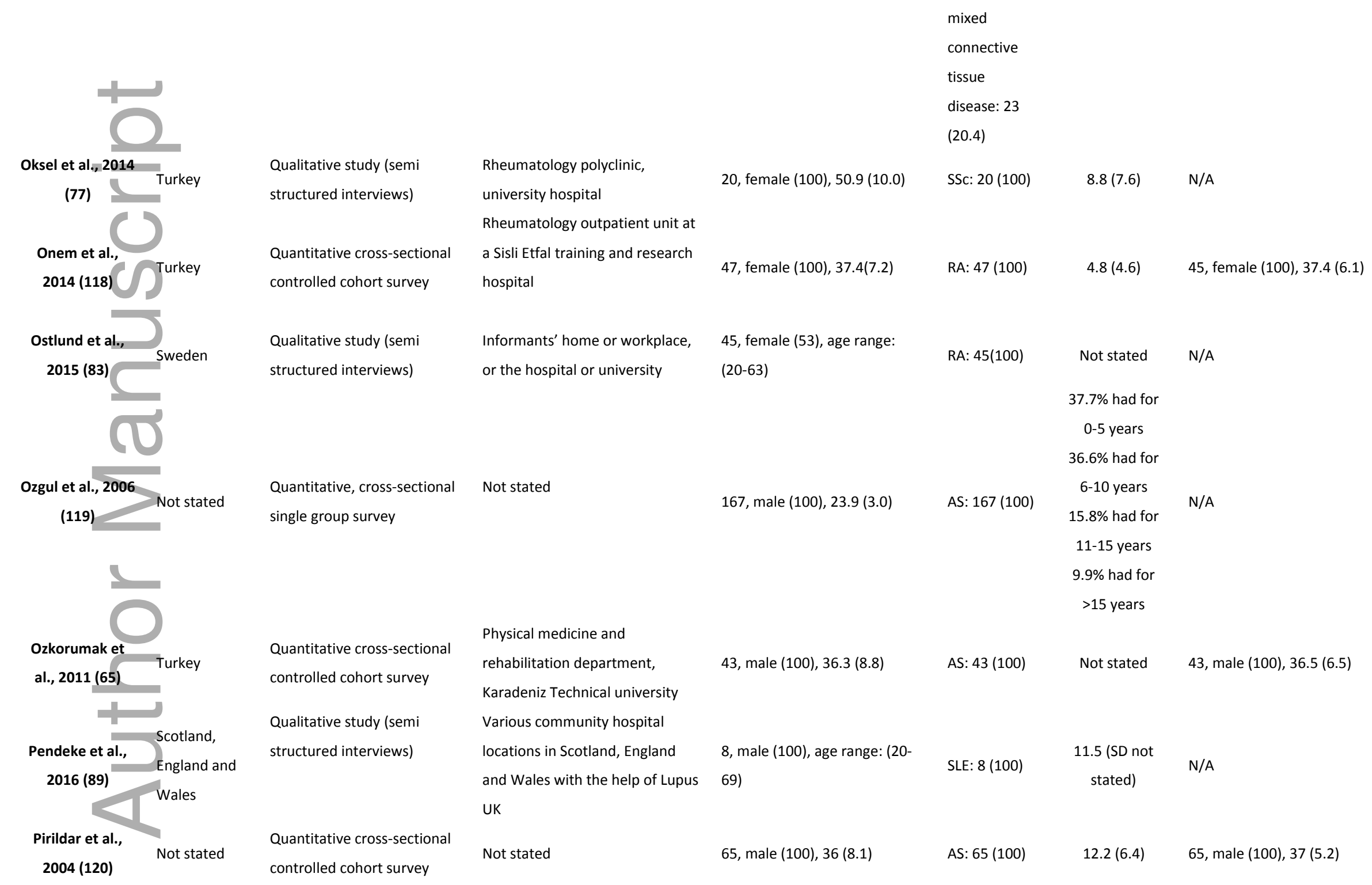

This article is protected by copyright. All rights reserved 


\begin{tabular}{|c|c|c|c|c|c|c|}
\hline $\begin{array}{c}\text { Priori et al., } 2015 \text { Italy } \\
\text { (87) }\end{array}$ & $\begin{array}{l}\text { Quantitative cross-sectional } \\
\text { controlled cohort survey }\end{array}$ & $\begin{array}{l}\text { Systemic sclerosis clinic, } \\
\text { university hospital }\end{array}$ & 24, female (100), $50.4(12.0)$ & SS:24 (100) & Not stated & 24 , female (100), $47.0(13.3)$ \\
\hline $\begin{array}{l}\text { Rezvani et al., } \\
2012 \text { (67) }\end{array}$ & $\begin{array}{l}\text { Quantitative cross-sectional } \\
\text { controlled cohort survey }\end{array}$ & $\begin{array}{l}\text { Rheumatology outpatient } \\
\text { clinic of a tertiary care centre }\end{array}$ & $\begin{array}{l}39 \text {, male }(100), 38 \text {, age range: } \\
(27-52)\end{array}$ & AS: 39 (100) & $4.4(1.9-26)$ & $\begin{array}{l}27 \text {, male }(100), 30 \text {, age range: (23- } \\
45)\end{array}$ \\
\hline $\begin{array}{l}\text { Rosato et al., } \\
2014 \text { (79) }\end{array}$ & $\begin{array}{l}\text { Quantitative cross-sectional } \\
\text { single group survey }\end{array}$ & $\begin{array}{l}\text { Scleroderma Centre of Clinical } \\
\text { Immunology and Rheumatology } \\
\text { clinic, tertiary hospital }\end{array}$ & 102 , female (100), $51(13)$ & SSc: 102 (100) & $8(6)$ & N/A \\
\hline $\begin{array}{l}\text { Rostom et al. } \\
2013 \text { (73) }\end{array}$ & $\begin{array}{l}\text { Quantitative cross-sectional } \\
\text { single group survey }\end{array}$ & Not stated & 110, male (100), 38.9 (12.5) & AS: $110(100)$ & $\begin{array}{c}9(0-40) \\
* \text { median (IQR) }\end{array}$ & N/A \\
\hline $\begin{array}{c}\text { Saadat et al., Iran } \\
2015 \text { (84) }\end{array}$ & $\begin{array}{l}\text { Quantitative cross-sectional } \\
\text { controlled cohort survey }\end{array}$ & $\begin{array}{l}\text { Rheumatologic ward, } \\
\text { Baquiyatallah tertiary hospital }\end{array}$ & 90, female (100), 40.1 (4.1) & RA: 90 (100) & Not stated & 110, female (100), $37.5(2.1)$ \\
\hline $\begin{array}{c}\text { Sanchez et al., France } \\
2016 \text { (90) }\end{array}$ & $\begin{array}{l}\text { Quantitative cross-sectional } \\
\text { single group survey }\end{array}$ & $\begin{array}{l}\text { Department of internal } \\
\text { medicine, Cochin hospital }\end{array}$ & 292, female (82.2), 55.9 (14) & SS: 292 (100) & $8.6(7.7)$ & N/A \\
\hline $\begin{array}{c}\text { Santana et al., } \\
2017 \text { (92) }\end{array}$ & $\begin{array}{l}\text { Quantitative cross-sectional } \\
\text { controlled cohort survey }\end{array}$ & $\begin{array}{l}\text { Rheumatology unit, university } \\
\text { hospital }\end{array}$ & 40 , male (100), $45.8(11.4)$ & AS: $40(100)$ & $\begin{array}{l}18(8.2-20.0) \\
{ }^{*} \text { median (IQR) }\end{array}$ & 40, male (100), $46.0(11.1)$ \\
\hline $\begin{array}{c}\text { Sariyildiz et al. } \\
2013 \text { (121) }\end{array}$ & $\begin{array}{l}\text { Quantitative cross-sectional } \\
\text { controlled cohort survey }\end{array}$ & $\begin{array}{l}\text { Two centres of physical medicine } \\
\text { and rehabilitation at university } \\
\text { hospitals }\end{array}$ & 70, male (100), $36.4(7.4)$ & AS: $70(100)$ & $9.9(6.9)$ & 60 , male (100), $35.2(7.7)$ \\
\hline $\begin{array}{c}\text { Sariyildiz et al., } \\
2013 \text { (22) }\end{array}$ & $\begin{array}{l}\text { Quantitative cross-sectional } \\
\text { controlled cohort survey }\end{array}$ & $\begin{array}{l}\text { Two centres of physical medicine } \\
\text { and rehabilitation at university } \\
\text { hospitals }\end{array}$ & 37 , female (100), $34.1(7.0)$ & AS: $37(100)$ & $8.6(7.4)$ & 33 , female (100), $33.5(6.2)$ \\
\hline $\begin{array}{l}\text { Schouffoer et al., Netherlands } \\
2009 \text { (98) }\end{array}$ & $\begin{array}{l}\text { Quantitative cross-sectional } \\
\text { controlled cohort survey }\end{array}$ & $\begin{array}{l}\text { Two academic rheumatology } \\
\text { outpatient university hospitals } \\
\text { Postal questionnaire to women }\end{array}$ & 37, female (100), 45.6 (9.5) & SSc: 37 (100) & $6.5(8.8)$ & 37 , female (100), $43.3(8.0)$ \\
\hline $\begin{array}{c}\text { Seawell et al., } \\
2005(60)\end{array}$ & $\begin{array}{l}\text { Quantitative cross-sectional } \\
\text { controlled cohort survey }\end{array}$ & $\begin{array}{l}\text { listed in database of NENYLFA } \\
\text { (North East New York Lupus } \\
\text { Foundation of America }\end{array}$ & $\begin{array}{l}54 \text {, female }(100), 47.4, \text { age } \\
\text { range: }(22-75)\end{array}$ & SLE: 54 (100) & Not stated & $\begin{array}{l}29 \text {, female }(100), 44.7 \text {, age range: } \\
(22-67)\end{array}$ \\
\hline
\end{tabular}

This article is protected by copyright. All rights reserved 


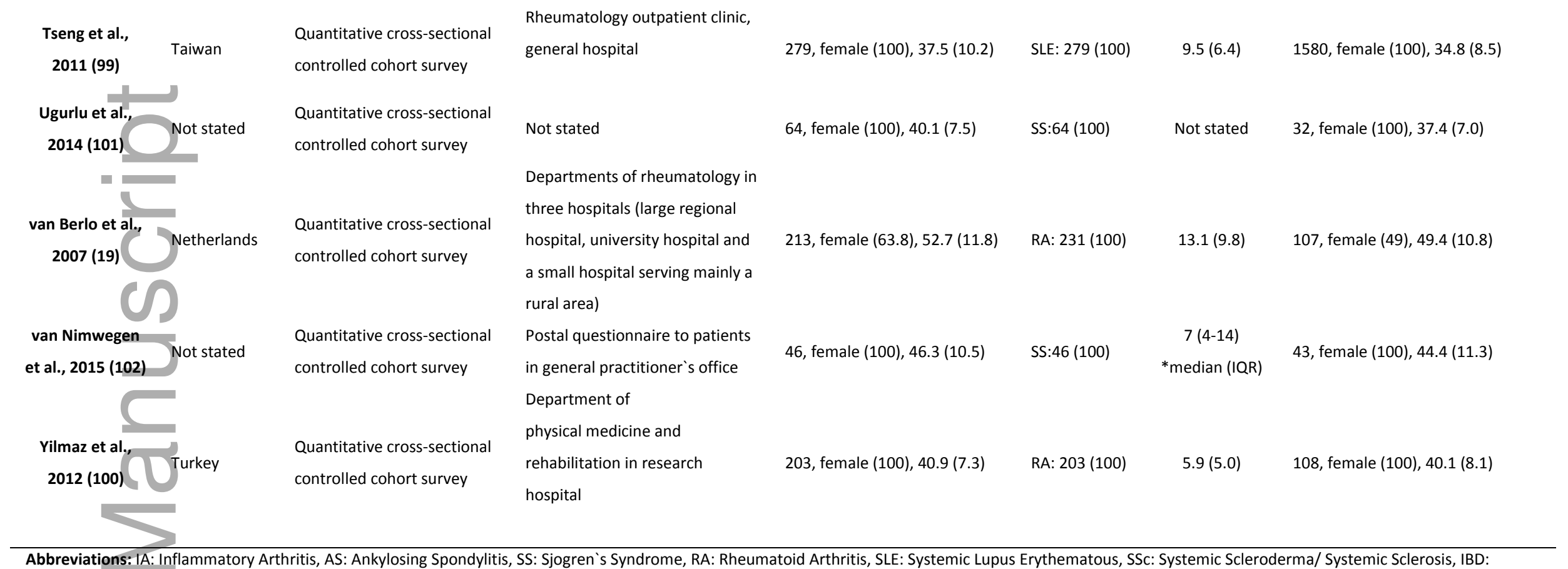

Irritable Bowel Disease, PsA: Psoriatic Arthritis, SpA: spondyloarthitis

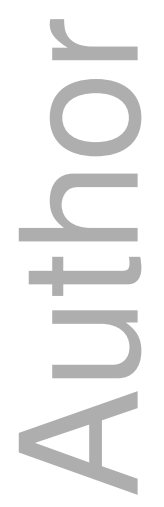

This article is protected by copyright. All rights reserved 
Table 2: Summary of outcome* and risk of bias assessment from quantitative studies. The two most common outcomes are presented (FSFI and IIEF), as well as other outcome measures reported in the included studies.

\begin{tabular}{|c|c|c|c|c|c|c|}
\hline \multirow[b]{2}{*}{ Study } & \multirow{2}{*}{$\begin{array}{l}\text { Female Sexual Function Index } \\
\qquad \begin{array}{c}\text { (FSFI) } \\
\text { mean (SD) }\end{array} \\
\text { IA Group } \quad \text { Control Group }\end{array}$} & \multirow{2}{*}{$\begin{array}{l}\text { International Index of Erectile Function } \\
\qquad \begin{array}{c}\text { (IIEF) } \\
\text { mean (SD) }\end{array} \\
\text { IA Group } \quad \text { Control Group }\end{array}$} & \multirow[b]{2}{*}{$\begin{array}{l}\text { Other outcome measure(s); scale (range); } \\
\text { interpretation }\end{array}$} & \multicolumn{2}{|c|}{ Other outcome measures } & \multirow[b]{2}{*}{$\begin{array}{c}\text { Overall Risk of } \\
\text { Bias: Total score } \\
10 \text { (Category) } \diamond\end{array}$} \\
\hline & & & & $\begin{array}{l}\text { IA Group } \\
\text { (mean (SD), } \\
\text { unless stated } \\
\text { otherwise) }\end{array}$ & $\begin{array}{c}\text { Control Group } \\
\text { (mean (SD), unless } \\
\text { stated otherwise) }\end{array}$ & \\
\hline $\begin{array}{c}\text { Abda et al., } \\
2016 \text { (85) }\end{array}$ & & & $\begin{array}{l}\text { Sexual disability and satisfaction questionnaire } \\
\text { derived from Health Assessment } \\
\text { Questionnaire (HAQ) Disability Index. Data } \\
\text { presented as N (\%) by grade (grade range: } 0 \text { - } \\
\text { 3), where lower grades indicate better sexual } \\
\text { function } \\
\text { Grade 0: able } \\
\text { Grade 1: mild } \\
\text { Grade 2: moderate } \\
\text { Grade 3: completely unable }\end{array}$ & $\begin{array}{l}\text { Grade 0: } 42(21) \\
\text { Grade 1: } 90(45) \\
\text { Grade 2: } 34(17) \\
\text { Grade 3: } 34(17)\end{array}$ & & $\begin{array}{c}5 \\
\text { (Moderate) }\end{array}$ \\
\hline $\begin{array}{l}\text { Aguiar et al., } \\
2014 \text { (74) }\end{array}$ & & & $\begin{array}{l}\text { Custom questionnaire; continuous scale (0- } \\
\text { 100), presented as mean (SD). Higher score } \\
\text { associated with higher satisfaction with sexual } \\
\text { life. }\end{array}$ & $52.3(31.0)$ & $57.6(29.9)$ & $\begin{array}{c}6 \\
\text { (Moderate) }\end{array}$ \\
\hline
\end{tabular}

This article is protected by copyright. All rights reserved 


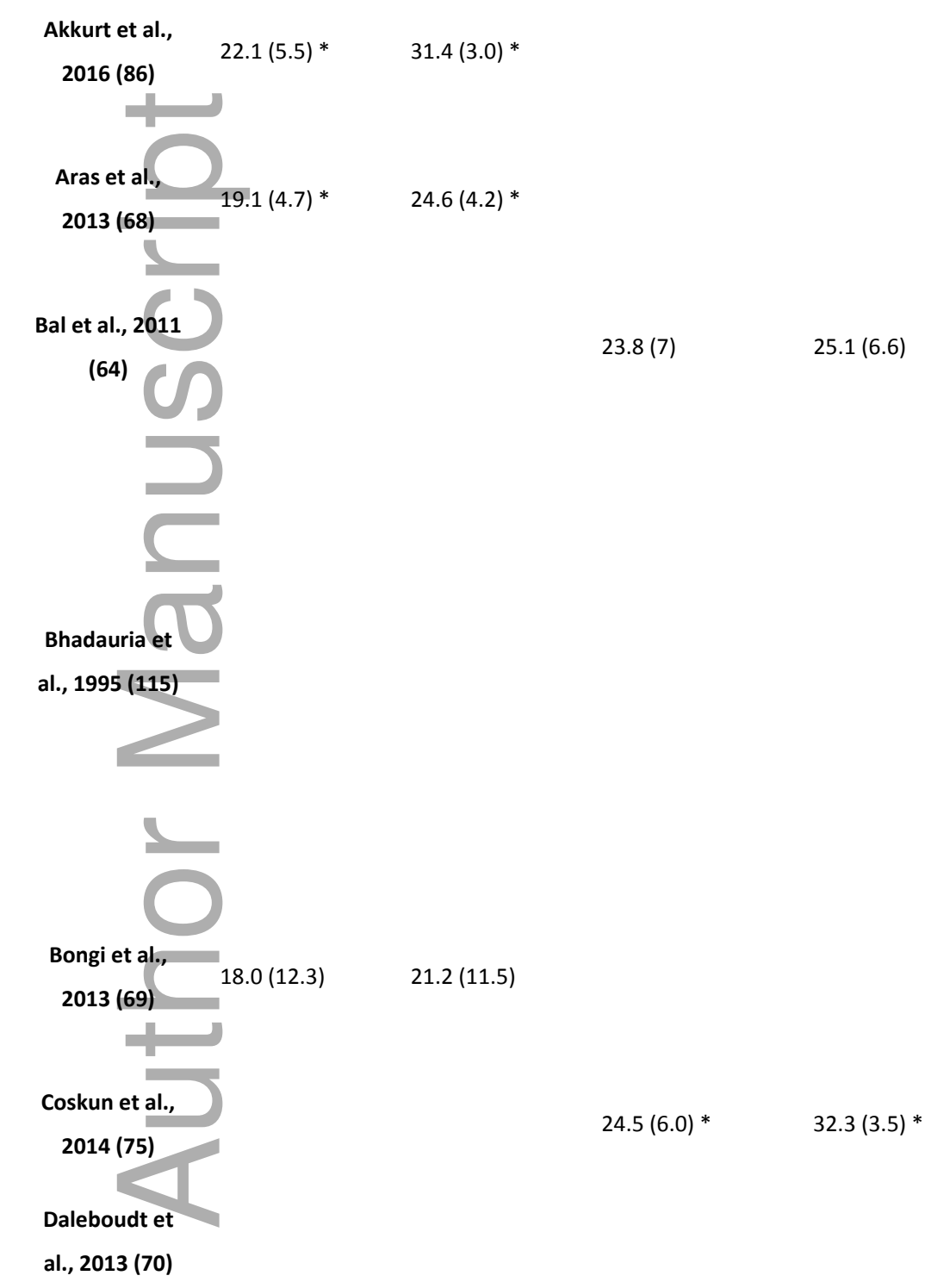
Sexual function and semi-quantitative sexual satisfaction index. Data presented as N (\%)

\section{patients reporting:}

Decreased frequency of intercourse:

Decreased orgasms:

Decreased intensity of orgasms:

(Moderate)

4

(Moderate)

5

(Moderate)

6

(Moderate)

$\begin{array}{ll}43.8(73) & 16.8(73) \\ 31.2(52) * & 3.9(17) * \\ 31.8(53) * & 2.3(10) *\end{array}$

(Moderate) 
$52.5(49.1)$

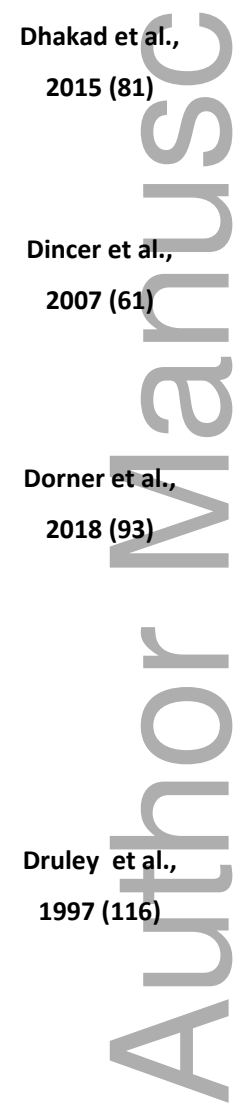

$20.5(7.1) *$

$24.9(3.8) *$

(Moderate)

\section{BMSFI;}

Total score: 0-44;

Lower scores indicate poor sexual function; no

threshold score provided

$28.9(8.4)^{*}$

$33.3(7.6)$ *

(Moderate)

Custom questionnaire;

$\mathrm{N}(\%)$ reported having some difficulty with

intercourse

$31.2(57.7)$

(Moderate)

QMI and a self-administered questionnaire

designed for study;

\section{Sexual intercourse:}

$\mathrm{N}(\%)$ reporting engaged

$\mathrm{N}(\%)$ reporting initiated

$34.8(47)$

$\mathrm{N}(\%)$ reporting avoided

$41.4(56)$

Foreplay:

(Moderate)

$N(\%)$ reporting engaged

$\mathrm{N}(\%)$ reporting initiated 
SHIM; N (\%) of patients reporting:

Mild erectile dysfunction:

Mild to moderate dysfunction:

Moderate erectile dysfunction:

Severe erectile dysfunction:

EIIF; $N$ (\%) of patients reporting:

No erectile dysfunction

$23(17.7)$

$25(19.2)$

$26(20.0)$

$14(10.8)$

$40(30.8)$

$18(36.7)$

$13(26.5)$

$2(4.1)$

Mild-moderate erectile dysfunction

Moderate erectile dysfunction:

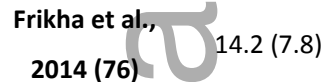

2014 (76)
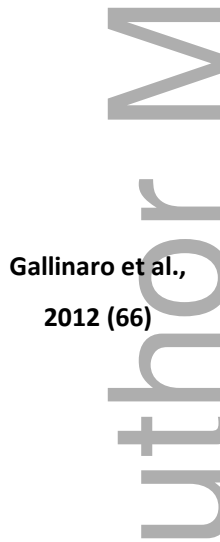

Garcia et al.,

2013 (72)

$24.5(8.0) * \quad 27.6(7.7) *$

(Moderate)

4

(Moderate)

6

(Moderate)

Sexual activity questionnaire; $N(\%)$ reporting:

Frequency of intercourse $\geq 2 \mathrm{x}$ a week:

$21.3(66.7)^{\wedge}$

$19.8(61.9)^{\wedge}$

$24(85.7)^{\wedge}$

Pain after sexual relationship:

$3(9.5)^{\wedge}$

$10.6(33.3)^{\wedge}$

$22.8(71.4)^{\wedge}$

$27.5(85.8)^{\wedge}$

$22.8(71.4)^{\wedge}$

$6.1(19.2)^{\wedge}$

$0(0)^{\wedge}$

$8(28.6)^{\wedge}$

$21(75.0)^{\wedge}$

$26(92.9)^{\wedge}$

$25(89.3)^{\wedge}$

$9.6(34.2)^{\wedge}$

This article is protected by copyright. All rights reserved 
(82)

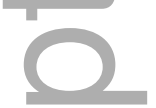

Healey et al.,

2009 (62)
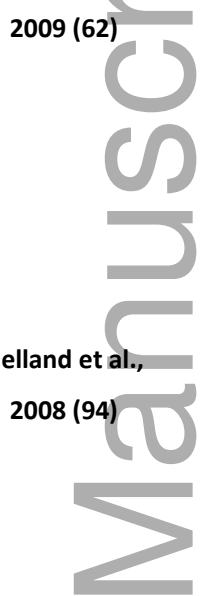

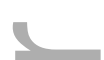

Hill et al., 2003

(8)

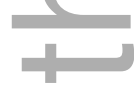

2009 (63)

Isik et al., $2017 \quad 17.2$ (SD not

reported) *
Extent AS affected intimate/sexual

relationships:

$\mathrm{N}(\%)$ reporting not at all or a little bit:

$\mathrm{N}(\%)$ reporting moderately to extremely:

$342(62)$

$210(38)$

Item 15 of the $15 \mathrm{D}$ generic/ standardized

HRQoL instrument;

$\mathrm{N}(\%)$ reporting impact on sexual activity:

No effect:

$257.3(31)$

315.4 (38)

$174.3(21)$

Considerable effect:

24.9 (3)

$58.1(7)$

Impossible:

Questionnaire previously developed for

patients with arthritis (130);

$N(\%)$ reporting impact of RA on relationship:

Not applicable:

No change:

$23(56)$

Changed:

$18(44)$
(Moderate)

(Moderate)

This article is protected by copyright. All rights reserved 


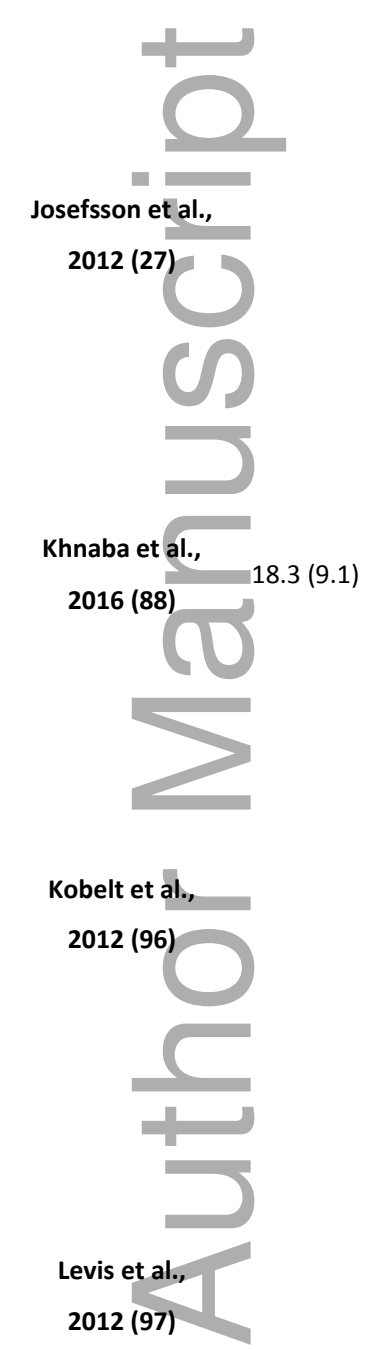

Questionnaire developed by authors;

$\mathrm{N}(\%)$ reporting:

Good or very good sexual well-being:

RA had negatively affected sexual health:

$55.5(37)$

Reduction in sexual desire due to RA:

$55.5(37)$

Continuing experience of decreased sexual

$93(62)$

desire:

$81(54)$

$64.5(43)$

Decreased sexual satisfaction due to RA

Weak or no sexual satisfaction:

$28.5(19)$

(High)

Self-assessed impact of RA on sexual activity questionnaire developed for study;

$\mathrm{N}(\%)$ reporting:

RA an obstacle for intimate relationship:

RA an obstacle for sexual relationships:

$864.3(68)$

RA to be a major obstacle for intimate

$966.0(76)$

(Moderate) relationships:

RA to be a major obstacle for sexual

$368.6(29)$

relationships:

419.4 (33)

9-item abbreviated version

of 19-item FSFI;

$\mathrm{N}(\%)$ reporting:

Sexually active:

296 (41)

$956(64)$

(Moderate) 


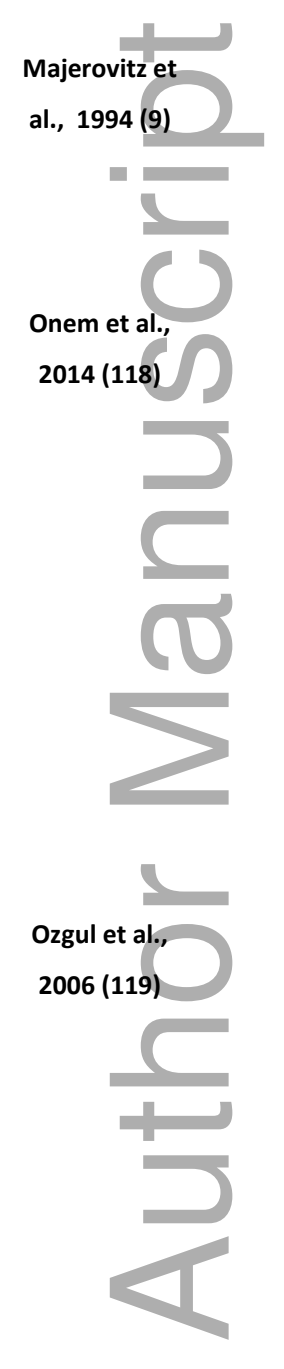

SDS;

Scale (5-25);

Higher scores indicating greater sexual

dissatisfaction

GRISS;

Scale (0-96);

Higher scores indicating greater sexual

dissatisfaction

SF-36;

$\mathrm{N}$ (\%) reporting:

Sexual intercourse

had troubles:

a little:

somewhat:

moderately:

very:

Sexual satisfaction

had troubles:

a little:

somewhat:

moderately:

very:

Sexual desire

had troubles:

a little:

\section{$M: 11.2(4.4)^{\wedge} \quad M: 10.8(3.6)^{\wedge}$}

F: $13.9(4.8)^{\wedge}$

$\mathrm{F}: 13.1(4.3)^{\wedge}$

(High)

$36.7(15.6)$

$88(52.7)$

40.4 (24.2)

36.7 (22.1)

$8.9(5.3)$

$1.8(1.1)$

$89(53.3)$

$47.3(28.3)$

$29.1(17.4)$

$9(5.4)$

$3.3(2.2)$

$78.5(47.0)$

$46.1(27.6)$

This article is protected by copyright. All rights reserved 


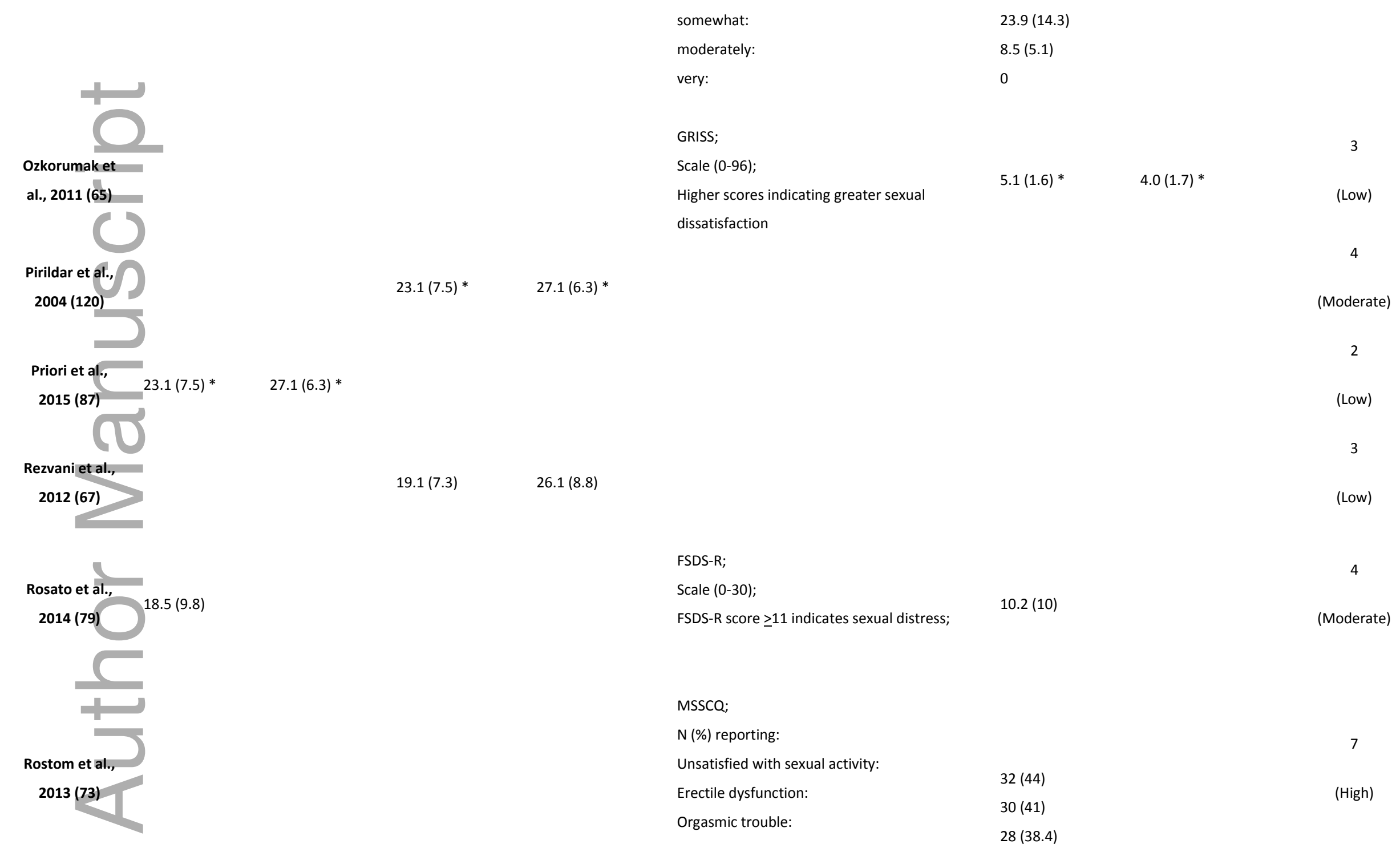

This article is protected by copyright. All rights reserved 
MSSCQ;

Range not stated;

Mean (SD);

Lower scores indicative of poorer sexual

function;

Desire:

Sensation:

Lubrication:

Cognition:

Orgasm:

Pain:

Enjoyment:

Partner related:

$\begin{array}{ll}17.6(5.5) & 17.9(3.8) \\ 12.2(4.5)^{*} & 13.7(4.5) * \\ 6.2(2.1) * & 6.9(2.1) * \\ 6.2(2.0) & 6.3(1.7) \\ 9.5(3.3) * & 10.4(2.9) * \\ 10.9(1.9)^{*} & 10.1(2.3) * \\ 21.3(7.5) * & 23.8(5.9) * \\ 7.7(2.4)^{*} & 8.5(1.8) *\end{array}$

$16(5.3)$

$29.0 *$

(median, SD not

reported)

\section{$22.0 *$ (median}

SD not reported)

$23.8(5.3)$ *

$27.0(2.1) *$
5

(Moderate)

(Moderate)

4

(Moderate)

(Moderate)

(Moderate)

This article is protected by copyright. All rights reserved 
SDS;

Scale (5-25);

$26.8(4.5)$ *

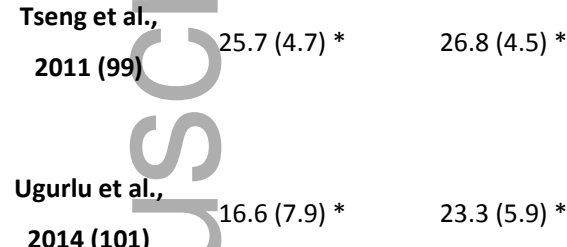
2014 (101)

$23.3(5.9)$ *

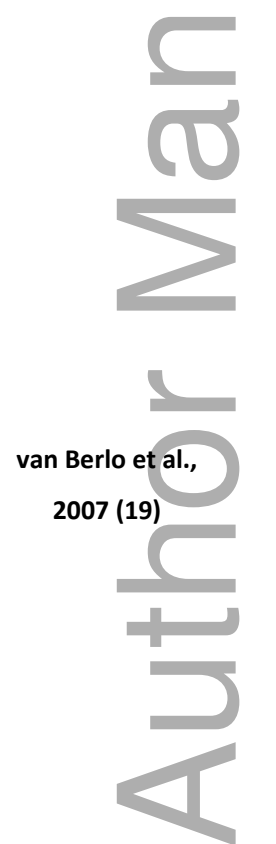

Seawell et al.,

$2005(60)$

-

2011 (99) $25.7(4.7)$ *

$16.6(7.9)$ *

al.,
Mean (SD);

Higher scores indicated greater dissatisfaction

$4.2(5.4)$

$13.6(3.2)$

(Moderate)

(Low)

(Moderate)

QSD;

Mean (SD);

Higher scores = greater intercourse frequency

and sexual satisfaction

Frequency sexual daydreams/fantasies (1-7):

M: 2.4 (1.5) M: $3.1(1.5)$

Frequency desire for sexual contact with

$F: 1.4(0.9)$ * F: $1.9(1.3)$ *

$M: 3.2(1.6)$ * M: $4.1(1.4)$ *

F: $2.9(1.4) \quad$ F: $3.4(1.3)$

$\mathrm{M}: 2.8(1.5) \quad \mathrm{M}: 3.5(1.3)$

$F: 3.2(1.5) \quad F: 2.7(1.4)$

M: $1.8(1.3) \quad M: 2.4(1.5)$

$\mathrm{F}: 1.2(0.8) * \quad \mathrm{~F}: 1.8(0.9) *$

Frequency sexual contact against will (1-7)

M: $1.0(0.0)$

M: $1.0(0.0)$

Sexual satisfaction (1-5);

$\mathrm{F}: 1.2(0.6)$

$F: 1.1(0.4)$

M: $3.6(0.9) \quad$ M: $3.6(0.8)$

F: $2.7(0.8) \quad$ F: $3.7(0.9)$

This article is protected by copyright. All rights reserved 


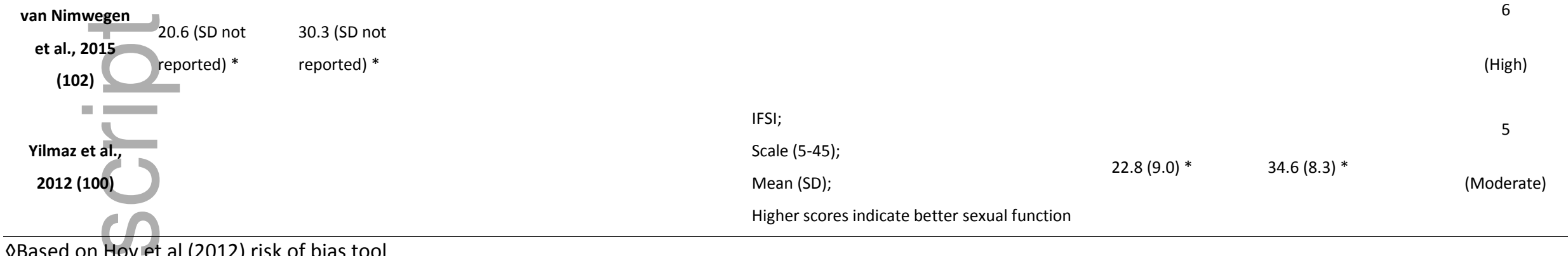

$\Delta$ Based on Hoy et al (2012) risk of bias tool

Low risk of bias: 0-3; Moderate risk of bias: 4-6 High risk of bias: 7-9, scored out of 10.

* indicates a statistically significant difference $(p<0.05)$ reported between groups in the study

$\wedge$ indicates groups were not compared using statistical analysis

Abbreviations:

ASES: The Arizona Sexual Experiences Scale

BMSFI: The Brief Male Sexual Function Inventory

FSDS-R: Female Sexual Distress Scale Revised

FSFI: Female Sexual Function Index, Score Range: 2-36, Scoring Direction: Sexual dysfunction indicated by score $\leq 26.5$ (123)

FSFI15: Female Sexual function in Scleroderma pilot questionnaire developed by the Robert Wood Johnson Scleroderma Program

GRSSS: Glombok-Rust Sexual Satisfaction Scale; $H A Q$

Health Assessment Questionnaire; IFSI: Index of Female Sexual Function

IIEF: International Index of Erectile Function scoring system, Score Range: 0-30, Scoring Direction: Sexual dysfunction indicated by score $\leq 25$ (43, 124)

MIS-SFQ: Medical Impact Scale of the Sexual Functioning Questionnaire

MSSCQ: Multidimensional Sexual Self-Concept Questionnaire

DSS: Sexual Dissatisfaction scale

This article is protected by copyright. All rights reserved 
PDSBE: Physical Disability and Sexual and Body Esteem Scale

QMI: Quality of Marriage Index

QSD: Questionnaire for screening sexual dysfunctions

SDS: Sexual dissatisfaction scale

SF-36: 36-item Short Form Health Survey

SHIM: Sexual Health Inventory for Men

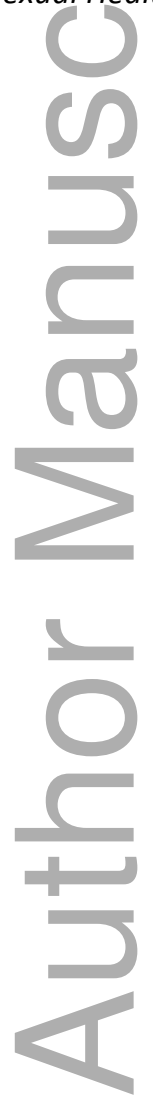

This article is protected by copyright. All rights reserved 
Table 3: Meta-synthesis of qualitative data

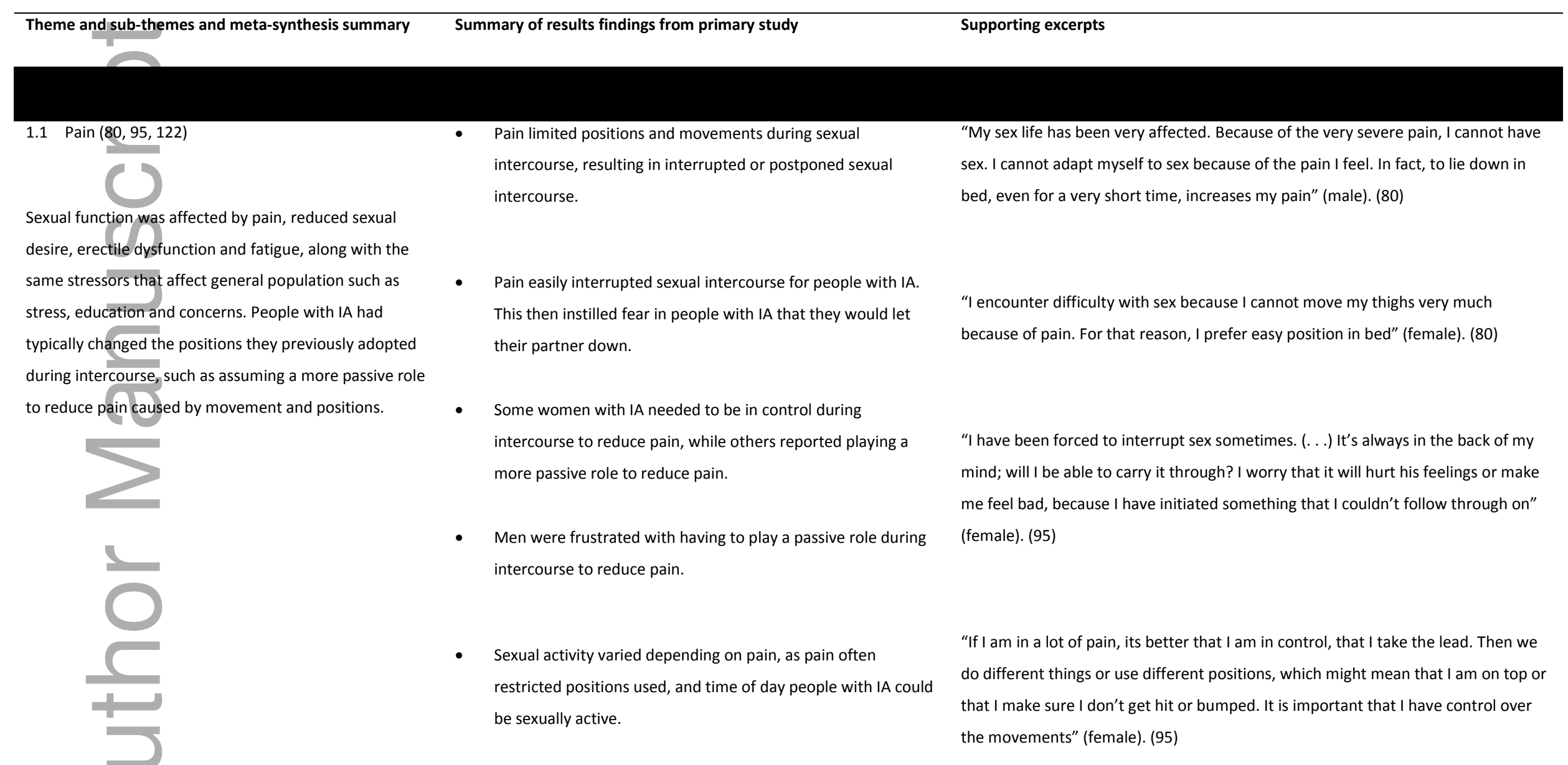

"My experience is that you really want to be active, but you end up with being passive, and that's not very exciting, is it? It does something with your self-esteem

This article is protected by copyright. All rights reserved 


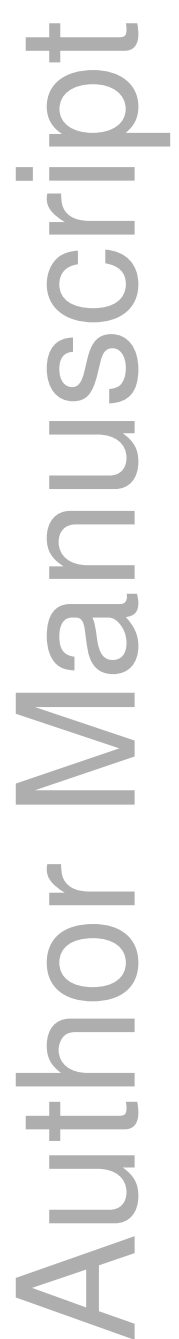

“It's irritating (being passive). Feeling that you can't do exactly what you want for yourself or to make it best for both of us" (male). (95)

“In other words I have a lot of pain ... you don't think about being intimate then, not that day anyway ... except I think it's important, on the other hand I think it's important with closeness, hugs, in other words that you, eh, that you kiss and hug but it can stop there, you don't have to go further ... sure, I can have pain then when I go to bed I can have pain even then, so I mean sure, it limits me ... it's probably not the first thing you think about when you have sex with someone, if you have pain I mean" (female) (122)

" [sex life] is limited sometimes ... sometimes it works well and sometimes it doesn't work at all, when I have pain it doesn't work and then, unfortunately, that's what's a bit annoying with it, she thinks [the wife] then, amongst other things" (male) (122)

“... she knows I have pain in my hands so that she can't have... can't take at any rate, you know ... Especially if you're lying and hugging, then your hands can get squeezed, you know. And that can really hurt. I'm more sore at night than .. because I've been busy and maybe worked, so maybe I'm more sensitive than in the mornings" (male) (122)

This article is protected by copyright. All rights reserved 
1.2 Erectile dysfunction $(89,95,122)$

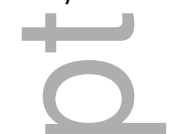

Erectile dysfunction largely contributed to male sexual dysfunction, which caused frustration, shock, stress and emasculation. Negative body image, reduced desire for intercourse, and erectile dysfunction all contributed to an altered sense of sexuality in men.
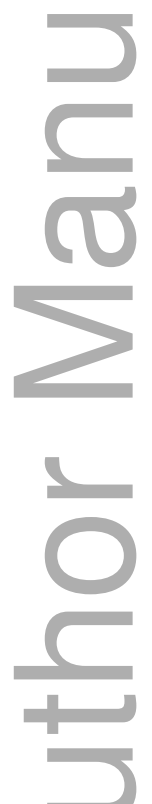

1.3 Fatigue and stressors $(8,95,122$

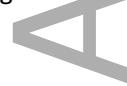

Fatigue reduced sexual desire and consequently the
- Men were particularly frustrated and stressed with the impact their disease had on erections and how to explain this to partners.

- Men were often shocked by the occurrence of erectile dysfunction and its threat to their masculinity.
“Getting an erection - everyone knows it's a really touchy area for men. I didn't think I would care about it so much, but I did. I would not have been so upset if it had been because my hip was so bad or my arm was like that" (male). (95)

“I met a girl last year ... and I didn't damn well know how I was going to bring it up because I knew he wasn't working as well as he had before 'John Thomas' ... but it petered out... because I explained to her that I had a bit of a problem with erections ... he's not dead... it works of course but ... dammit" (male) (122)

"Sexual relations with my wife have suffered immensely.... As a husband I'm frustrated because it's taken away my ability to perform for the wife sexually. I did not see this coming at all. It's depressing, being a man on paper not one defined by their ability." (male) (89)

"Where it matters most as a husband I have failed her. I have not been able to make love to my wife owing to erectile dysfunction caused by this condition. She probably sees me as half a man, if at all." (male) (89)

- $\quad$ Fatigue reduced sexual desire and consequently the frequency of sexual intercourse. This was not an issue for some couples in long-term relationships
"Sometimes I am so tired and in pain that sex is the last thing I think about. A cuddle is just as nice." (female) (8)

This article is protected by copyright. All rights reserved 
frequency of sexual intercourse, but this wasn't an issue

for some couples in long-term relationships.

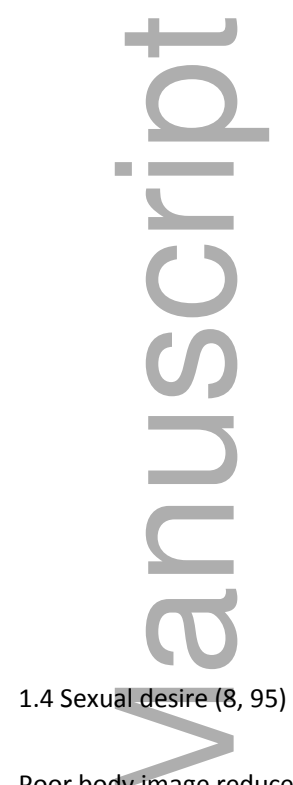

Poor body image reduced the sexual desire in both male and female people with IA and restricted people with IA from finding partners in the first place.

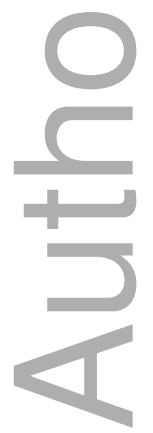

- Sex life was not affected by IA alone, but also by the same stressors that affect the general population.
"I believe that you possibly do get more tired and need to go to bed early at night and you might choose to get a good night's sleep instead (of having sex). Well, several of my medicines do list this as a side-effect saying that it can affect sexual desire, but that's hard to judge, I don't really know, I can't say, well, yes it is tiredness that affects me most... but I don't think my husband thinks like that, like he needs to take my illness into consideration, so it is the same thing there, because I don't feel that I am suffering from an illness he doesn't either need to treat me as being ill." (female) (122)

"Sexual life is so incredibly susceptible to everything, it's so much in life that affects; stress, education, and concerns. So my experience is that many are concerned that they do not want too much put on the disease. There is so much in life in general that affect sexuality - okay, there are some drawbacks with it (the disease), but we experience many of the same stressors as healthy people do" (female) (95)

- IA reduced desire for intercourse causing substantial guilt for some people

"The disease has had a huge impact on my sex life. Not in terms of physical problems, but sex drive. It's really reduced" (male) (95)

- A loss of desire for intercourse led to a sense of impaired masculinity.

- Body image, particularly for females, reduced desire for physical intimacy due to not feeling attractive. to pull my weight etc." (male) (8)

"The disease has had a huge impact on my sex life. Not in terms of physical problems, but sex drive. It's really reduced" (male) (95)

"In bad periods with a lot of activity, I feel rotten inside and then sex is not foremost in my mind. I feel very unattractive and tend to say no thanks" (female)

This article is protected by copyright. All rights reserved 


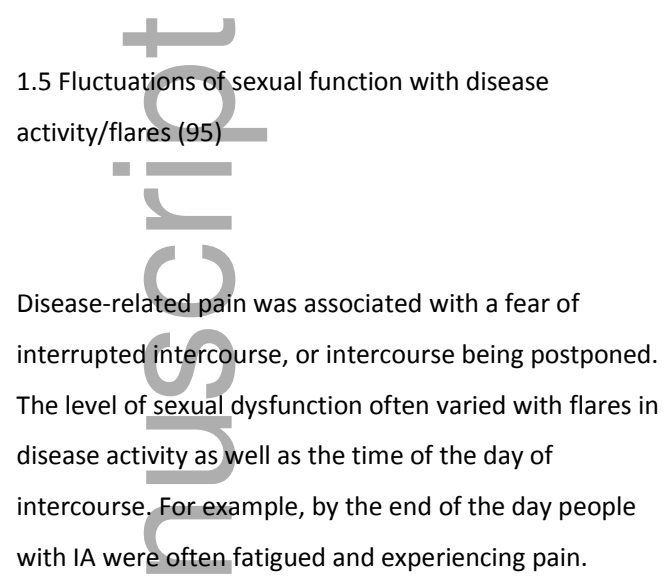

1.5 Fluctuations of sexual function with disease activity/flares (95)
-

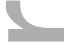
with IA were often fatigued and experiencing pain.

Disease-related pain was associated with a fear of

interrupted intercourse, or intercourse being postponed.

The level of sexual dysfunction often varied with flares in

disease activity as well as the time of the day of

intercourse. For example, by the end of the day people

- Sexual ability fluctuated depending on symptoms associated with IA disease activity. Intercourse was most often interrupted during disease flares.

- Sexual intercourse was not considered important for people with IA, particularly during disease flares.
"Fluctuations in the disease and symptoms restrict my sex life. Sometimes it poses a problem, very often it doesn't. It's very up and down - there's no pattern" (female) (95)

"When you can hardly move, and you have pain in your entire body, sex isn't exactly what's on your mind" (female) (95)

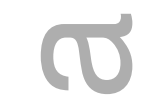

2.1 Reduced frequency of sexual activity (95)

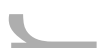

Intimate relationships tended to transition towards caring and less physical nature as the importance of sexual intercourse was reduced, particularly during disease flares.

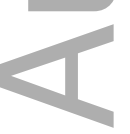

- $\quad$ Reduced importance of sexual life was highlighted. A greater need for caring relationships was identified.

"The only thing I needed was a shoulder to cry on and an arm that cared and didn't mind. Our exciting sex life turned into more of a deeply caring relationship, which was really great" (female) (95)

- $\quad$ People with IA were concerned that their partners would not accept them
"Especially I think mentally ... and you can feel really bad and you think yeah but, think if this continues, that I'm going to ... feel like this and I'm going to look like

This article is protected by copyright. All rights reserved 


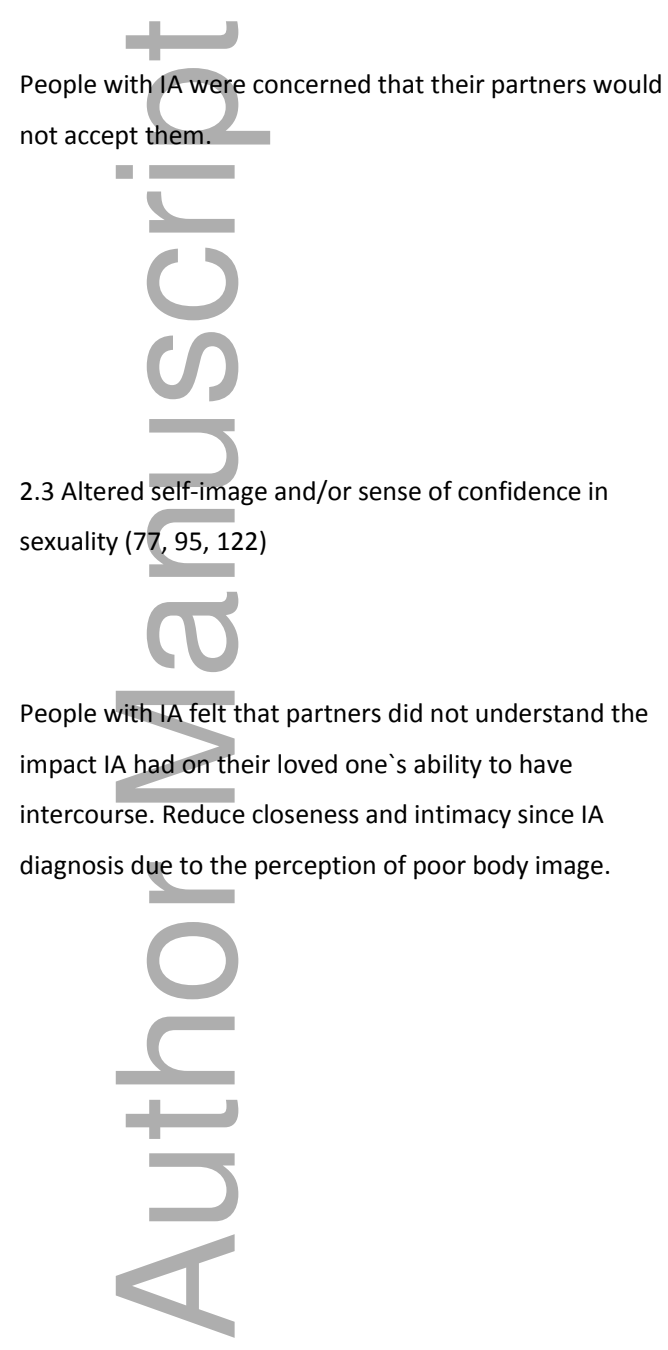

this, is he going to accept me then because sex is a big part of a relationship ... I think it, eh, affects it a lot, and as I said, then it's how you feel on and off too ... yes, it's [fear] that he's going to leave me and then l'll be sad and have low self-esteem also then, it leaves a mark, now I haven't been in a situation where it really has been a disaster, luckily, because I think it really would be, something that would sit emotionally for both of us I think, that the other one would maybe be, yeah but as my boyfriend then he' $d$ be a little like this, a-ha, how is this actually going to work, will she be able to have sex with me in two years ... that's how I feel ... odd." (female) (122)

- People felt that partners did not understand the impact IA had on their loved one's ability to have intercourse

- People with IA reported a reduced closeness and intimacy since their diagnosis due to the perception of poor body image

- A negative body image perceived by people with IA impaired their sexuality

- The impact IA had on body image restricted people from finding partners.
“... and I get tired and difficult when I' $m$ with her ... you have to try and be considerate all the same, show that ... but she always looks at me when I'm in pain ... but then she thinks I'm not enough maybe, all the time ... if we're sitting and hugging and feeling good, then I don't want to do it, then I'd rather pull ... away or, more accurately, push her away, unfortunately ... I'm a failure. That's why I think she doesn't always accept the disease, but it's just how it is ... I think that's the hardest thing right now, that you can't validate your wife when she maybe needs it, ... but that's always something you have to work on ... as long as you have rheumatism anyway." (male) (122)

"It had a huge impact on our sex life that he never seemed to understand that I was exhausted or in pain until I couldn't sit down, go to the toilet or walk. Then he understood, and that hurt my feelings" (female) (95)

"My husband has become estranged from me since the diagnosis" (female) (77)

This article is protected by copyright. All rights reserved 


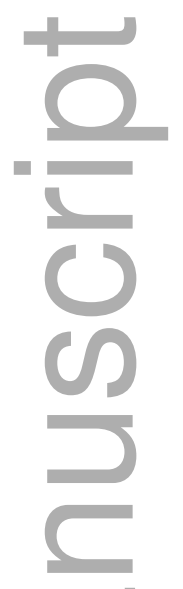

2.4 Altered relationship with partner $(8,80,89,95)$

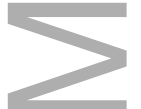

Despite the sexual dysfunction associated with ron

IA, women often felt pressured to maintain a

normal sex life to prevent relationships being affected by the disease. Some partners had greater acceptance and understanding of the impact IA had on sexual function than others, assisting to strengthen relationships between partners. Conversely, others experienced that their partners poorly understood the impact of IA on their ability to engage in intercourse, creating tension and fear of relationship instability.

"I can feel very, what shall I say, unsexy, when I can barely even walk, eh, and my hands especially, aren't particularly beautiful, because they have bumps and I can't move them so well back and forth" (female) (122)

"It's not easy to find a man (. . .) I often think that nobody could love me the way I look now, because I look awful, don't I?" (female) (95)

- Some women felt they had to push themselves to have intercourse despite reduced desire and fatigue, as they feared partners would leave them or didn't want their sexual relationships to be affected by the disease.

- Some women felt the need to maintain a normal sex life for their partners despite the presence of sexual dysfunction

- Some partners had greater acceptance and understanding of the impact IA had on sexual function than others, assisting to strengthen relationships. Conversely, others experienced that their partners poorly understood the impact of IA on their ability to engage in intercourse, creating tension and fear of relationship instability.
"I have pushed myself. Even if I was exhausted, I have made a really big effort. I don't want all the reasons he is with me to disappear" (female) (95)

"My husband and I have been married for 30 years and we have always had a loving sexual relationship. He is not over demanding which is most probably a good thing, but I do believe it is important, with all my problems to still have a normal sex life." (female) (8)

This article is protected by copyright. All rights reserved 


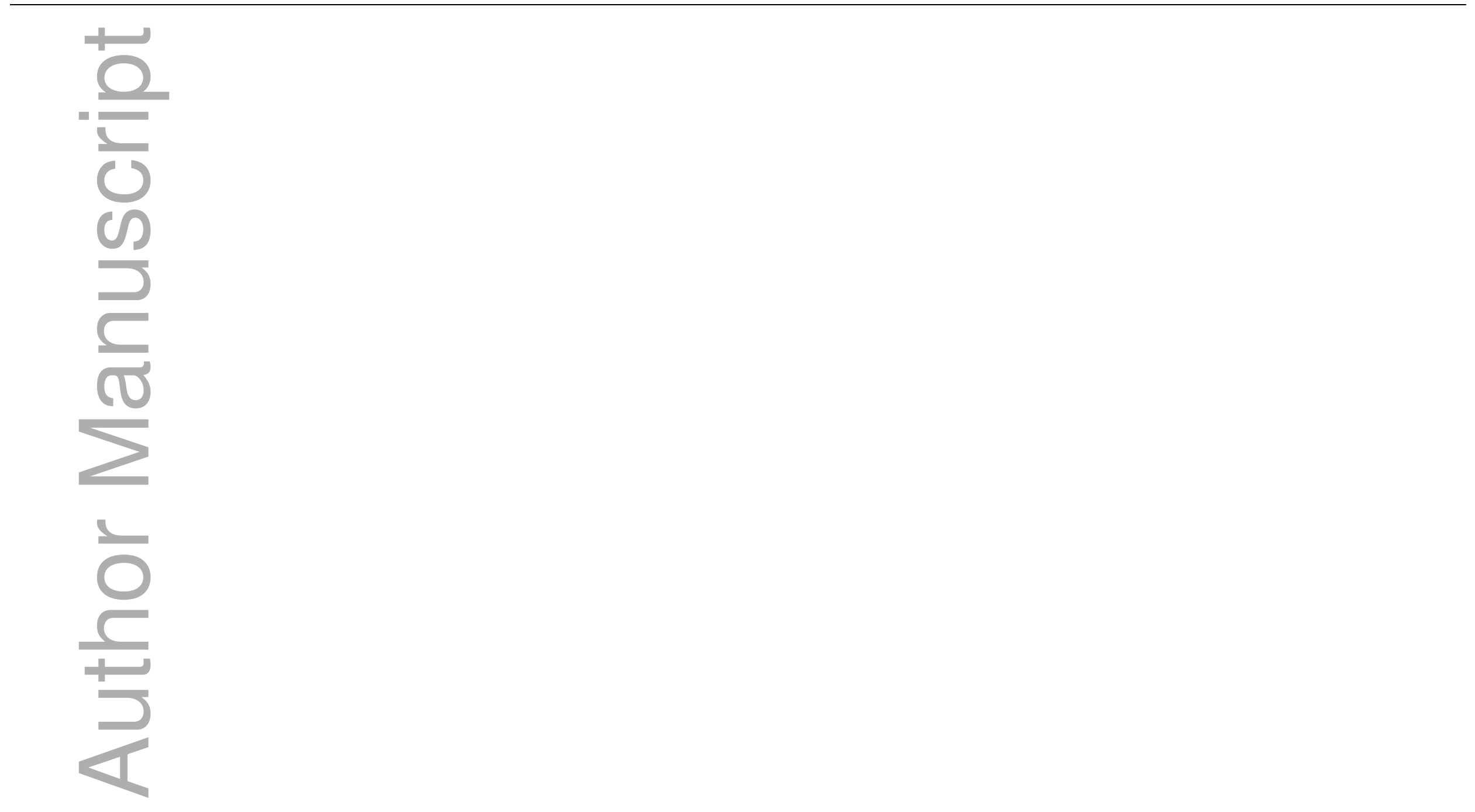

This article is protected by copyright. All rights reserved 


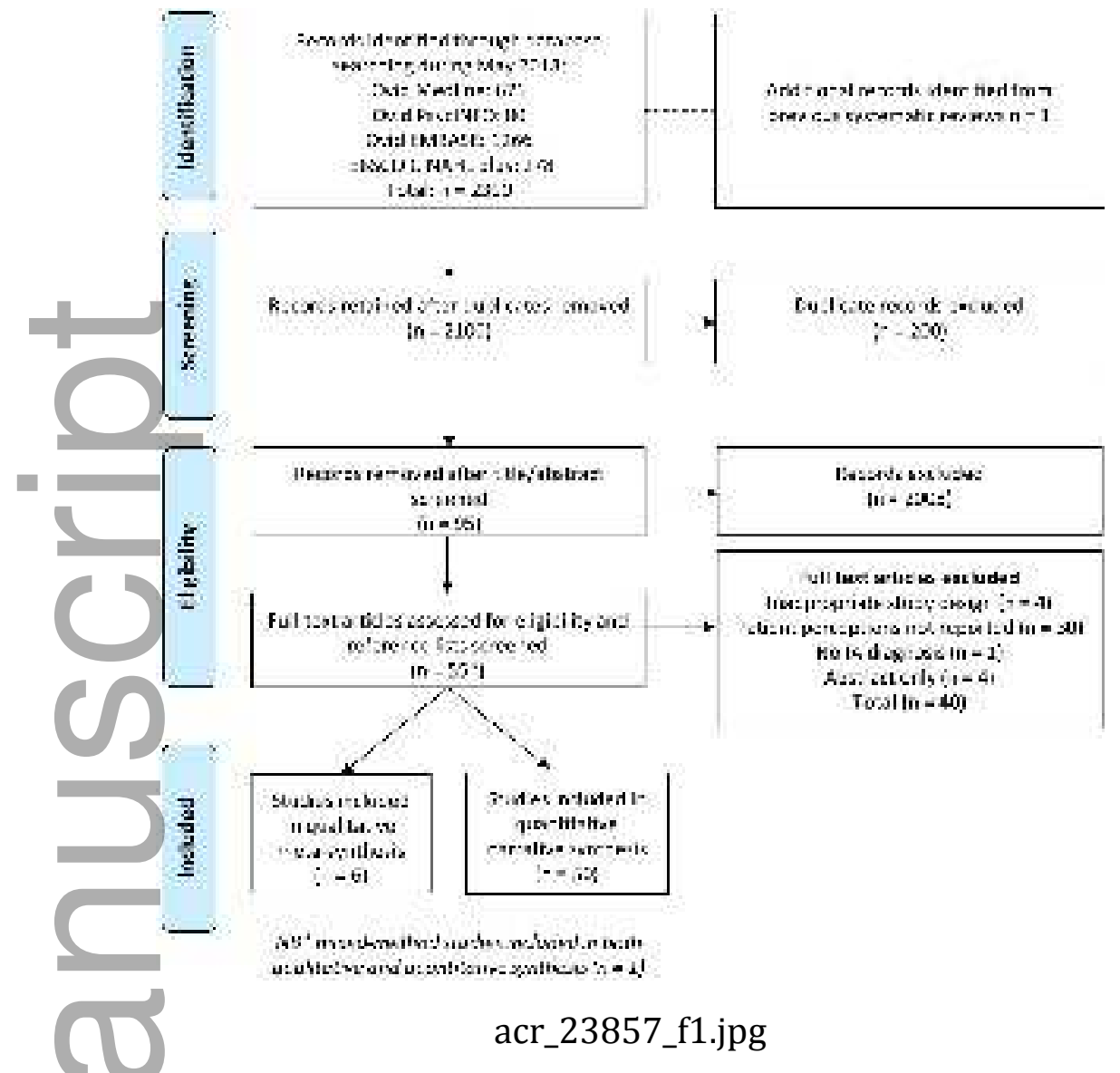

This article is protected by copyright. All rights reserved 

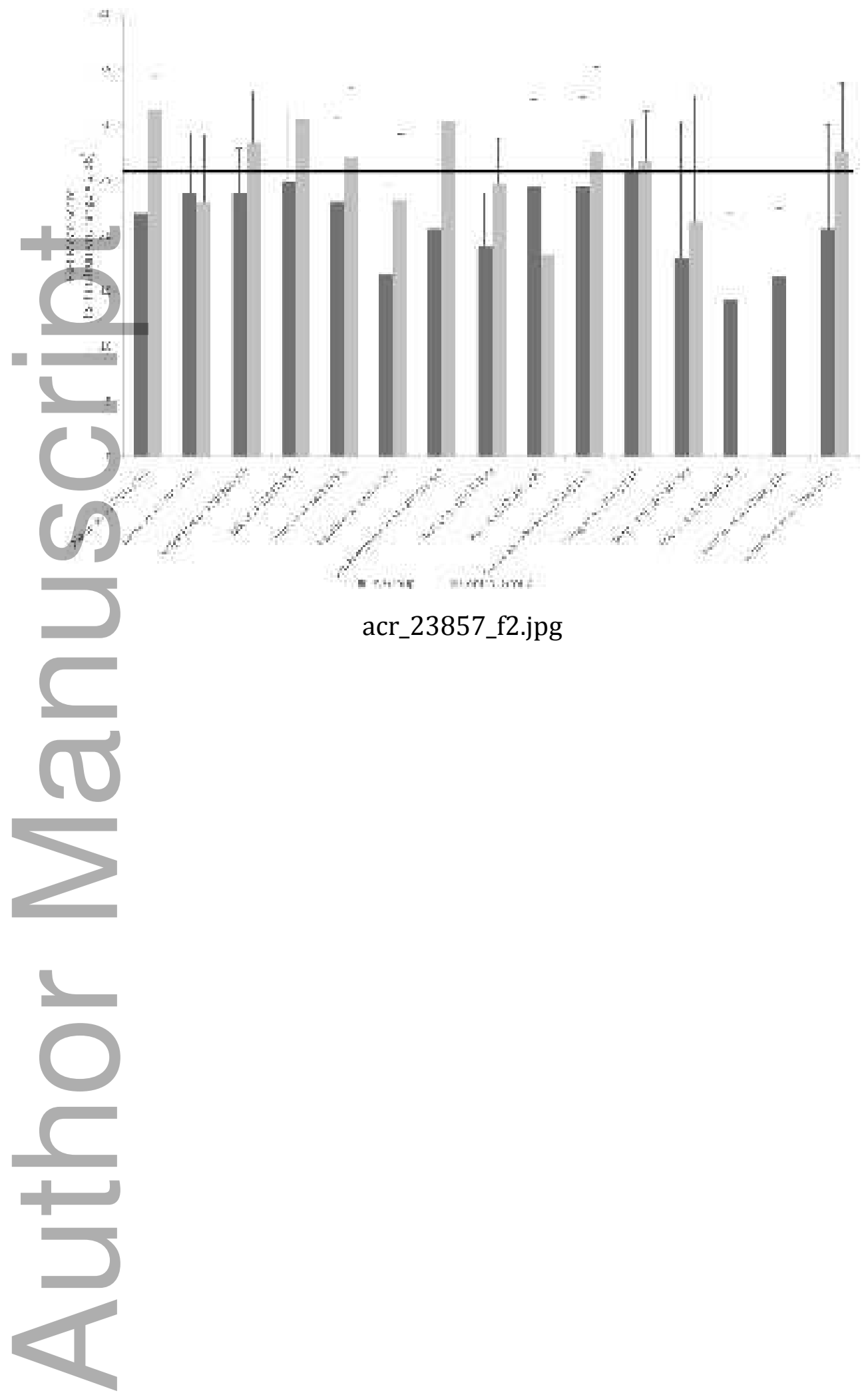

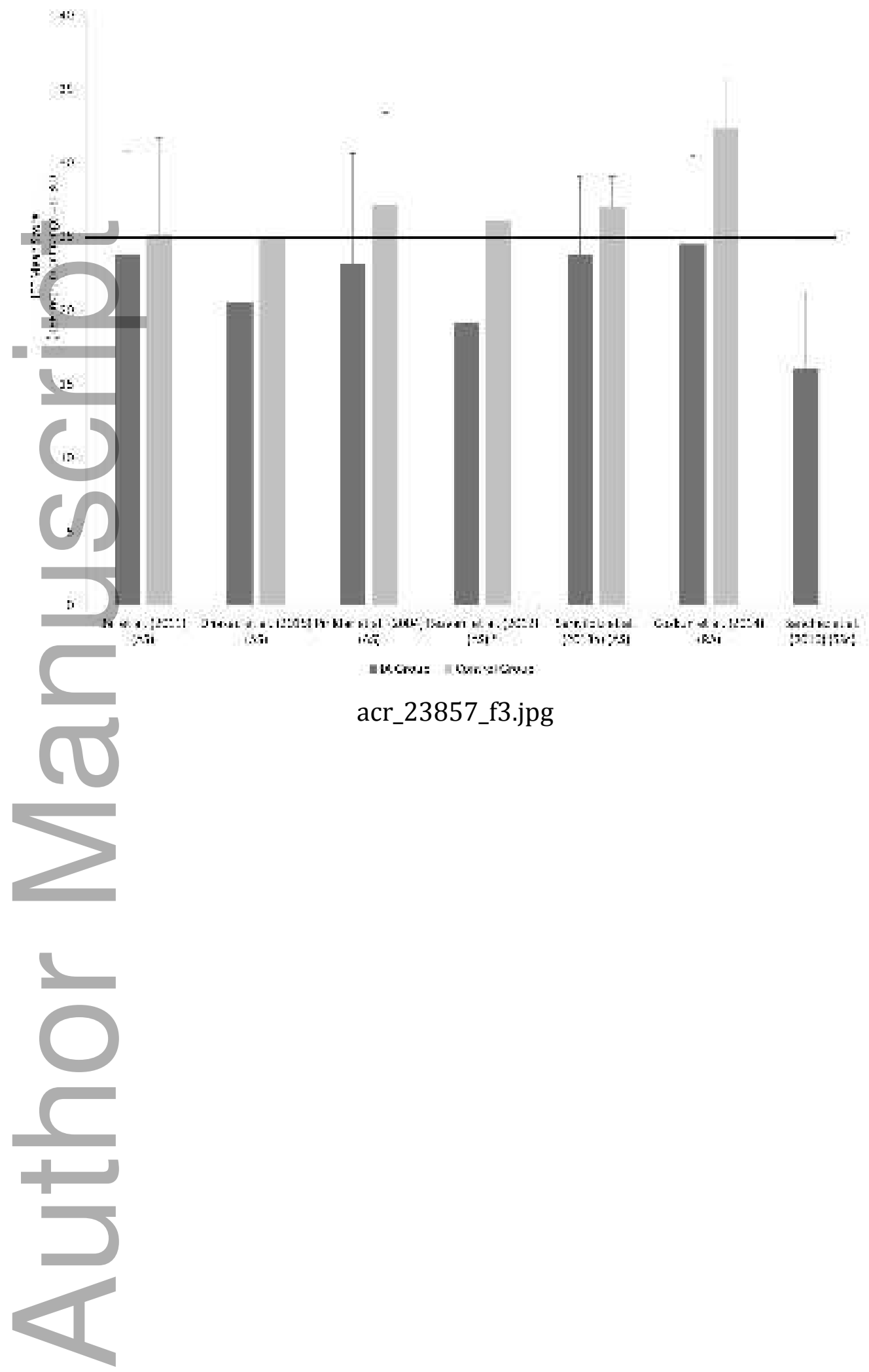


\section{University Library}

\section{- M M N E R VA A gateway to Melbourne's research publications}

Minerva Access is the Institutional Repository of The University of Melbourne

Author/s:

Restoux, LJ;Dasariraju, SR;Ackerman, IN;Van Doornum, S;Romero, L;Briggs, AM

Title:

Systematic Review of the Impact of Inflammatory Arthritis on Intimate Relationships and Sexual Function

Date:

2020-01-01

\section{Citation:}

Restoux, L. J., Dasariraju, S. R., Ackerman, I. N., Van Doornum, S., Romero, L. \& Briggs, A. M. (2020). Systematic Review of the Impact of Inflammatory Arthritis on Intimate Relationships and Sexual Function. ARTHRITIS CARE \& RESEARCH, 72 (1), pp.41-62. https://doi.org/10.1002/acr.23857.

Persistent Link:

http://hdl.handle.net/11343/286791 